\title{
Changing depositional environments in the semi-restricted Late Jurassic Lemeš Basin (Outer Dinarides; Croatia)
}

\author{
Michael A. J. Vitzthum ${ }^{1} \cdot$ Hans-Jürgen Gawlick ${ }^{1} \cdot$ Reinhard F. Sachsenhofer ${ }^{1} \cdot$ Stefan Neumeister ${ }^{1,2}$
}

Received: 16 August 2021 / Accepted: 23 November 2021 / Published online: 18 December 2021

(c) The Author(s) 2021

\begin{abstract}
The up to $450 \mathrm{~m}$-thick Upper Jurassic Lemeš Formation includes organic-rich deep-water (max. 300 m) sedimentary rocks deposited in the Lemeš Basin within the Adriatic Carbonate Platform (AdCP). The Lemeš Formation was investigated regarding (1) bio- and chemostratigraphy, (2) depositional environment, and (3) source rock potential. A multi-proxy approachmicrofacies, Rock-Eval pyrolysis, maceral analysis, biomarkers, and stable isotope ratios-was used. Based on the results, the Lemeš Formation is subdivided from base to top into Lemeš Units 1-3. Deposition of deep-water sediments was related to a late Oxfordian deepening event causing open-marine conditions and accumulation of radiolarian-rich wackestones (Unit 1). Unit 2, which is about $50 \mathrm{~m}$ thick and Lower early Kimmeridgian (E. bimammatum to S. platynota, ammonite zones) in age, was deposited in a restricted, strongly oxygen-depleted basin. It consists of radiolarian pack- and grainstones with high amounts of kerogen type II-S organic matter (avg. TOC $3.57 \mathrm{wt} . \%$ ). Although the biomass is predominantly marine algal and bacterial in origin, minor terrestrial organic matter that was transported from nearby land areas is also present. The overlying Unit 3 records a shallowing of the basin and a return to oxygenated conditions. The evolution of the Lemeš Basin is explained by buckling of the AdCP due to ophiolite obduction and compressional tectonics in the Inner Dinarides. Lemeš Unit 2 contains prolific oil-prone source rocks. Though thermally immature at the study location, these rocks could generate about $1.3 \mathrm{t}$ of hydrocarbon per $\mathrm{m}^{2}$ surface area when mature.
\end{abstract}

Keywords Outer Dinarides · Kimmeridgian · Organic-rich deposits · Anoxia · Depositional environment

\section{Introduction}

The Jurassic-to-Paleogene Adriatic Carbonate Platform (AdCP: Vlahović et al. 2005) is dominated by shallowwater carbonates. However, Kimmeridgian-to-Tithonian deep-water ( 200 to $300 \mathrm{~m}$ ) carbonates, siliceous rocks, and black shales occur within the Lemeš and Gorski Kotar Basins (Fig. 1).

Two contrasting tectonic models exist for the genesis of the Lemeš Basin.

Hans-Jürgen Gawlick

gawlick@unileoben.ac.at

1 Department of Applied Geosciences and Geophysics, Montanuniversitaet Leoben, Peter-Tunner-Straße 5, 8700 Leoben, Austria

2 Montanbehörde West-Abteilung IV/7, Bundesministerium Für Landwirtschaft, Regionen Und Tourismus, Aignerstraße 10, 5026 Salzburg, Austria
In one model, the elongated southeast-northwest trending Lemeš Basin formed in the platform interior (see also Fig. 1c) at the onset of intense block-faulting and subsidence at the northeastern AdCP margin during the early Kimmeridgian. This is believed to have been influenced by oceanic spreading in the Vardar Ocean (Bucković et al. 2004, following Herak 1986). Normal-faulting and extensional subsidence resulted in the deposition of the deep-water bituminous limestones in this basin during a time of otherwise global eustatic sea-level fall (Bucković et al. 2004; Haq et al. 1988).

In contrast, Velić et al. (2002a, b and references therein) assumed that the newly formed intraplatform basins reflect a transpressional stress regime with the formation of small pull-apart basins and nearby uplift zones with emersion and facies differentiation.

In the type area of the Lemeš Basin in the Svilaja Mts. (Fig. 1), the deep-water Lemeš Formation (LemešSchichten: Furlani 1910) records a continuous deepening above shallow-water limestones with the "stromatoporid" 

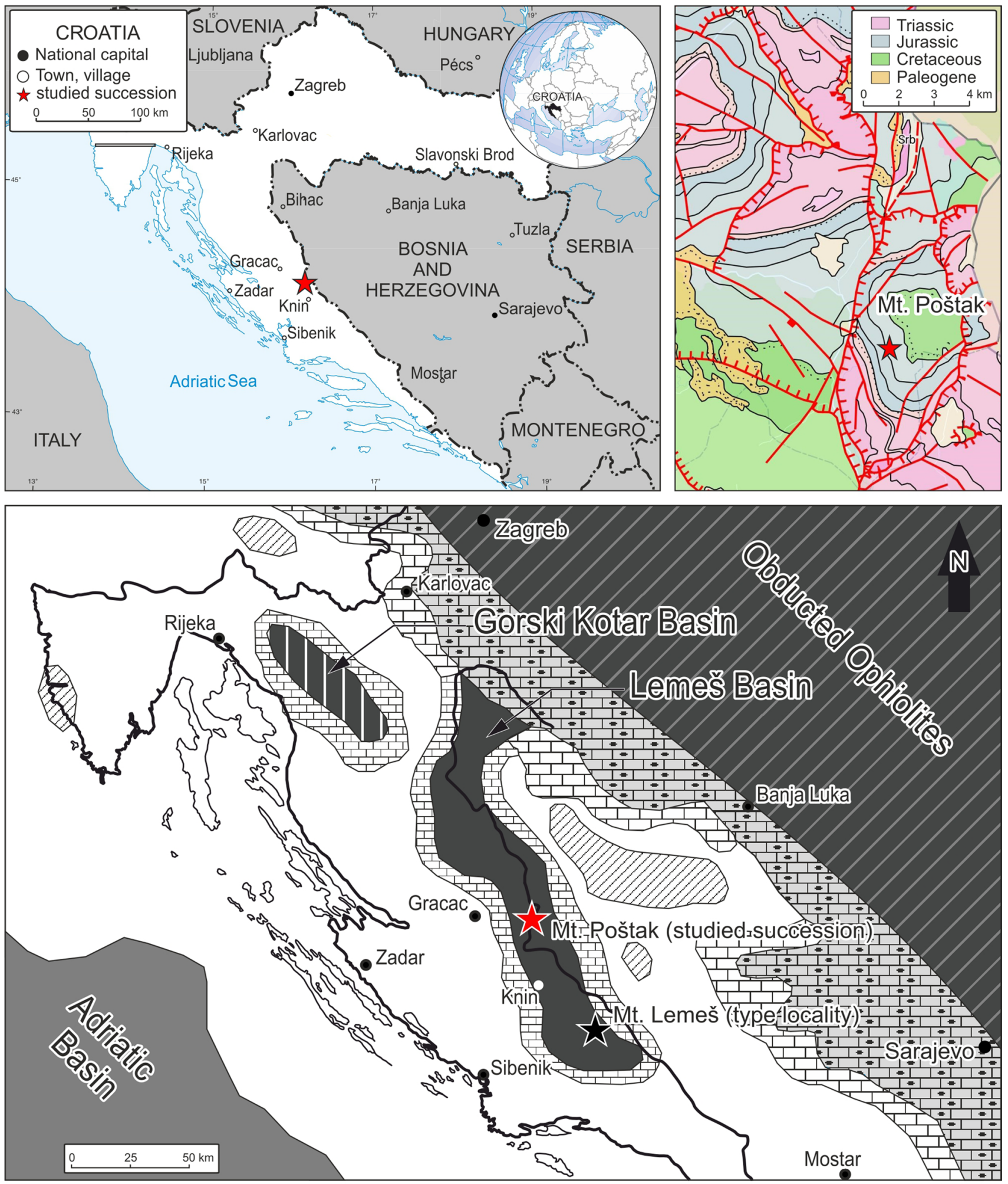

$\square$ deep-water facies (Adriatic Basin)

$\square$ shallow-water facies (AdCP)

$\square$ intraplatform deep-water (Lemeš Basin)

पD over-deep lagoon (Gorski Kotar Basin)

居国 deep-water foreland (radiolarite) reefs (hydrozoan and coral)

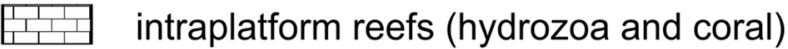

$\square / \triangle$ emerged areas

estimated westernmost limit of the obducted Neo-Tethys ophiolites 
4 Fig. 1 a Location of the study area in southern Croatia. (GPS: $44^{\circ} 13^{\prime} 59.94^{\prime \prime} \mathrm{N} 16^{\circ} 66^{\prime 23.79 \prime}$ E), b geological map of the area of Mt. Poštak (after Hrvatski geološki institut 2009a; b), and c map of the present-day position of the Kimmeridgian/early Tithonian AdCP, the estimated deep-water foreland (radiolarite) basins in front of the obducted Neo-Tethys ophiolites (after Velić et al. 1994, 2002a, b), modified according to new results

sponge Cladocoropsis sp. (Kerner 1907). The transition between the shallow-water limestones of the AdCP and the deep-water Lemeš Formation was dated by the presence of Kimmeridgian aged ammonoids in the siliceous deep-water limestones (Furlani 1910).

In the study area (Fig. 1), the Lemeš Formation has a slightly different lithological evolution due to the more central palaeogeographic position in the newly formed Late Jurassic basin. Furthermore, the transition from shallowto deep-water limestones is older than in the type region. Based on the depositional history and facies of the Lemeš Formation as defined by Furlani (1910), the roughly timeequivalent siliceous bedded limestones of the Gorski Kotar Basin do not belong to the Lemeš Formation (see also Velić et al. 1994). Inclusion of the Gorski Kotar Basin limestones in the Lemeš Formation led to erroneous palaeogeographic and tectonic reconstructions (Blažeković Smojić et al. 2009).

Siliceous and organic-rich deposits are widespread within the sedimentary succession of the AdCP (see also Jacob et al. 1983; Sebecic and Ercegovac 1983; Barić et al. 1988; Moldowan et al. 1992; Mattavelli et al. 1993; Jerinic 1994; Cota and Baric 1998; Radovčić et al. 1983; Fiket et al. 2008). There is no evidence to correlate these organic-rich strata with global or Tethys-wide oceanic anoxic events (OAEs) (Jenkyns 2010). Therefore, they represent deposits in local, periodically restricted basins. This necessitates an in-depth investigation of the geodynamic, palaeoclimatic, and eustatic sea-level controls leading to deposition of the organic-rich sedimentary rocks in the Upper Jurassic Lemeš Basin.

The black shales within the Lemeš Formation were subject to preliminary sedimentological and geochemical investigations (Bulić and Trutin 1996; Fiket et al. 2008; Blažeković Smojić et al. 2009). However, detailed investigations into the vertical variation of the depositional environment during the basin evolution have not previously been undertaken.

To fill this gap, the organic-rich part of the Lemeš Formation was sampled at high resolution and various geochemical methods were applied to the sample set. The geochemical assessment was accompanied by organic petrographic analysis. The geochemical and petrographical results are complemented by microfacies analysis, which also include the under- and overlying strata. The comprehensive interpretation of all data provides information on the depositional environment, with significant implications for a new depositional model. Additional biostratigraphic results improve the age constraints of the main stages of the Lemeš Basin evolution. These data also provide new insights into the regional, Upper Late Jurassic, Dinaridic tectonic regime, which was caused by ophiolite obduction, and its effects on the evolution of intra-platform basins of the AdCP. Additionally, the hydrocarbon potential of the Lemeš Formation is quantified.

\section{Geological setting}

The investigated succession is located at the slope of Mt. Poštak (Fig. 1) in southwestern Croatia. The region consists of the Triassic-to-Lower Jurassic AdCP basement and Toarcian-to-Lower Cretaceous AdCP stratigraphic units. These represent the majority of the Outer Dinarides carbonate succession (Vlahović et al. 2005).

The Late Jurassic AdCP interior is known for its diverse facies and deep-water depositional environments (i.e., Lemeš and Gorski Kotar Basins; Vlahović et al. 2001; Fig. 1), which followed a long-lasting Middle Jurassic-toOxfordian shallow-water depositional environment (Tišljar et al. 1994; Velić et al. 1994, 2002b; Lawrence et al. 1995; Vlahović et al. 2005). The Lemeš Basin sediments are siliceous and organic-rich carbonate deposits restricted to deep intraplatform areas with low oxygen exchange (Tišljar et al. 1994; Velić et al. 1994, 2002b; Vlahović et al. 2005; Blažeković Smojić et al. 2009; Bucković and Markić 2016). The Kimmeridgian aged lower Lemeš Formation, known as the Bänderkalk, is characterized by thin-bedded and strongly fractured grey cherty limestone, intercalated by very finegrained white platy limestones (Furlani 1910). The middle Lemeš Formation, known as the Fleckenkalk, is represented by thick-bedded, grey, and bioturbated limestones with irregular chert nodules. The highest stratigraphic unit at the type locality is described as a 20-30 m-thick succession of Tithonian, bedded, and bioturbated grey limestone with aptychi. The lateral continuation of the Lemeš Formation shows a gradual change from deep basin limestones to peri-reefal and reefal facies (Furlani 1910). The age dating of the Lemeš Formation at the type locality at Mt. Lemeš is based on (late) Kimmeridgian and early Tithonian ammonites, i.e., Oppelia sp., Perisphinctes sp., Aspidoceras sp., Haploceras sp., and Belemnoidea sp. (Furlani 1910).

Based on dasycladalean algae and foraminifera from the Lemeš Formation and age equivalent deposits in the Gorski Kotar Basin, Velić et al. (1994, 2002a, b), Bulić and Trutin (1996), and Velić (2007) confirmed a Kimmeridgian-to-early Tithonian age. However, these authors also emphasized the difficulties to define strict boundaries for distinct biozones.

The Lemeš Basin extends over $42 \mathrm{~km}^{2}$ (Fig. 1c). The 250-450 m-thick basin fill has been subdivided into different 
mappable layers (Blažeković Smojić et al. 2009 and references therein; Fig. 2). The lower part of the basin fill comprises thick limestone layers with chert lenses and nodules (layer 1) overlain by platy siliceous and cherty limestones (layer 2, Fig. 2). An overlying tuff layer (layer 3) records volcanic activity (Blažeković Smojić et al. 2009). The

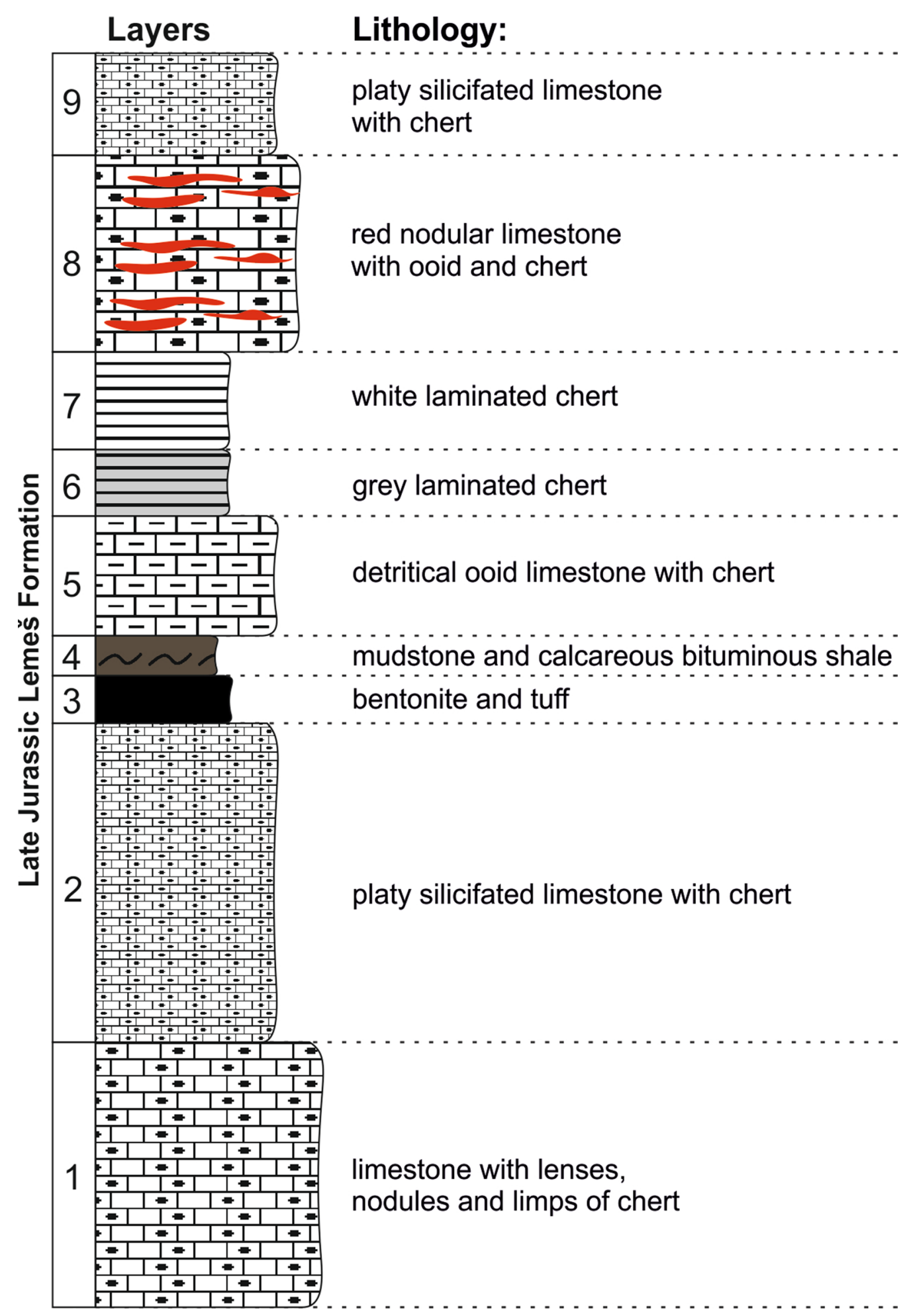

Fig. 2 Subdivision of the Lemeš Formation into layers 1-9 and the original lithological description after Blažeković Smojić et al. (2009 and references therein). The authors do not provide a vertical scale, but the entire formation is $250-450 \mathrm{~m}$ thick 
presence of bentonite suggests an average $\mathrm{pH} \sim 8$ during diagenesis, typical for deep-marine intraplatform settings (Šegvić et al. 2006). Similar remnants of volcanic activity were evident from pyroclasts at the base of the Gorski Kotar Basin (Bucković and Markić 2016).

The succession changes upward into organic-rich mudstones (layer 4, Fig. 2), which are 2-70 m thick. The calcareous shales are dark brown-grey, olive-grey, dark grey, brown-black, and/or grey-black, and show mm-scale lamination. Bed thickness typically varies from 10 to $65 \mathrm{~cm}$, but may reach $3 \mathrm{~m}$. According to Blažeković Smojić et al. (2009), the dominant fossils assemblages include radiolarians, juvenile ammonoids, aptychi, calpionellids (sic! in Oxfordian-Kimmeridgian sedimentary rocks), and Saccocoma. The organic-rich layer 4 is overlain by siliceous limestones with ooids reworked from shallow-water areas (layer 5), grey laminated limestones (layer 6), and whitish laminated chert (layer 7, Fig. 2). The upper part of the Lemeš Formation includes thick, red, nodular, partly cherty limestones with detrital components and ooids (layer 8), and thin-bedded siliceous platy limestones (layer 9, Fig. 2) This reflect a shallowing upward trend (Blažeković Smojić et al. 2009 and references therein).

Geochemical investigations of the organic matter-rich layer 4 have been performed by Blažeković Smojić et al. (2009) using sample material from eight sites in the Lemeš Basin. The most important results are briefly summarized below: total organic carbon (TOC) contents up to 27 wt.\% (typically 2-6 wt.\%) and hydrogen index (HI) values between 253 and $637 \mathrm{mgHC} / \mathrm{gTOC}$ (average: $518 \mathrm{mgHC} /$ gTOC) prove a good petroleum source potential. High sulphur (S) contents (8-11.5 wt.\%) of kerogen concentrates suggest the presence of sulphur-rich kerogen type II-S. Based on $T_{\max }$ values, layer 4 is thermally immature in the southern $\left(411-416^{\circ} \mathrm{C}\right)$ and northern part of the Lemeš Basin $\left(424-425^{\circ} \mathrm{C}\right)$ but reaches early oil window maturity in its middle part (435-437 $\left.{ }^{\circ} \mathrm{C}\right)$. Biomarker analysis suggests marine microbes as dominant organic matter source (Bulić and Trutin 1996; Fiket et al. 2008; Blažeković Smojić et al. 2009). According to Blažeković Smojić et al. (2009), uniform geochemical features reflect similar depositional conditions and organic input in most parts of the Lemeš Basin.

\section{Studied succession and samples}

The investigated succession of the Lemeš Formation is located at the southeastern slope of Poštak mountain (GPS: $44^{\circ} 13^{\prime} 59.94^{\prime \prime} \mathrm{N} 16^{\circ} 6^{\prime} 23.79^{\prime \prime}$ E, see also Fig. 1), where it overlies Oxfordian lagoonal limestones (Tišljar and Velić 1993; Veseli et al. 2012). Here, the Lemeš Formation is about $270 \mathrm{~m}$ thick (Figs. 3, 4) and comprises the entire fill of the Lemeš Basin (Fig. 4a). Its lower part, the Rastičevo member (Veseli et al. 2012) is approximately $100 \mathrm{~m}$ thick and is characterized by silicified pack- and wackestones with open-marine organisms (ammonoids and radiolaria) in its upper part. The transition to the overlying Dimici member (Veseli et al. 2012; Figs. 3, 4a) is marked by two distinct claystone layers, interpreted in the field as silicified ash layers. Unit 2 is $55 \mathrm{~m}$ thick and consists of siliceous limestones with intercalated organic-rich layers (black shales). The overlying 110 m-thick Lemeš member (Veseli et al. 2012) above the black shales consists of limestone with ammonoids and cherty nodules, and is increasingly intercalated by calciturbidites. Near the top of the Lemeš member, siliceous packstones with shallower water organisms become dominant.

The main focus of the present study is on the organic matter-rich Dimici member (Unit 2). Hence, 185 samples (geochemical profile, Fig. 3), representing each of the exposed layers have been taken for geochemical analysis. Unfortunately, outcrop conditions prevented continuous sampling. Two additional samples were collected from the basal volcanic ash layers for XRD analysis. Rastičevo member (Unit 1) is recorded with 17 samples (geochemical profile, Fig. 3) for geochemical analysis and nine samples for microfacies analysis. The sample set of Unit 3 comprises four ammonite samples and eight samples for microfacies analysis. Two claystone layers have been selected for XRD analysis.

\section{Analytic methods}

Total carbon (TC) and sulphur (S) were determined for 202 samples using a Leco 300 CS analyser. Samples treated with hydrochloric acid to remove carbonate-bound carbon were analysed for TOC. The concentration of total inorganic carbon $(\mathrm{TIC}=\mathrm{TC}-\mathrm{TOC}$ ) was used to determine the percentage of calcite equivalent $(\mathrm{Ceq} .=\mathrm{TIC} \times 8.33)$. Rock-Eval pyrolysis was performed on a Delsi Rock Eval II + instrument to determine the amount of free hydrocarbons (HCs) $\left(S_{1}: \mathrm{mg}\right.$ $\mathrm{HC} / \mathrm{g}$ rock), $\mathrm{HCs}$ generated during gradual heating $\left(S_{2}: \mathrm{mg}\right.$ $\mathrm{HC} / \mathrm{g}$ rock), and the temperature of maximum $\mathrm{HC}$ generation $\left(T_{\max }\right) . S_{1}$ and $S_{2}$ were used for the calculation of the hydrogen index $\left(\mathrm{HI}=\left[S_{2} / \mathrm{TOC}\right] \times 100\right)$, the petroleum potential $\left(\mathrm{PP}=\left[S_{1}+S_{2}\right]\right)$, and the production index $\left(\mathrm{PI}=S_{1} /\left[S_{1}+S_{2}\right]\right)$ (Lafargue et al. 1998).

Thirty-one rock samples selected for biomarker analysis were extracted with dichloromethane in a Dionex ASE 200 accelerated solvent extractor $\left(75^{\circ} \mathrm{C} ; 50 \mathrm{bar}\right)$. After evaporation of the solvent in a Zymark TurboVap 500 closed cell concentrator, asphaltenes were precipitated from a hexane-dichloromethane solution (80:1) and separated using centrifugation. The hexane soluble fraction was separated into NSO compounds, saturated hydrocarbons, and aromatic hydrocarbons by medium-pressure liquid chromatography 


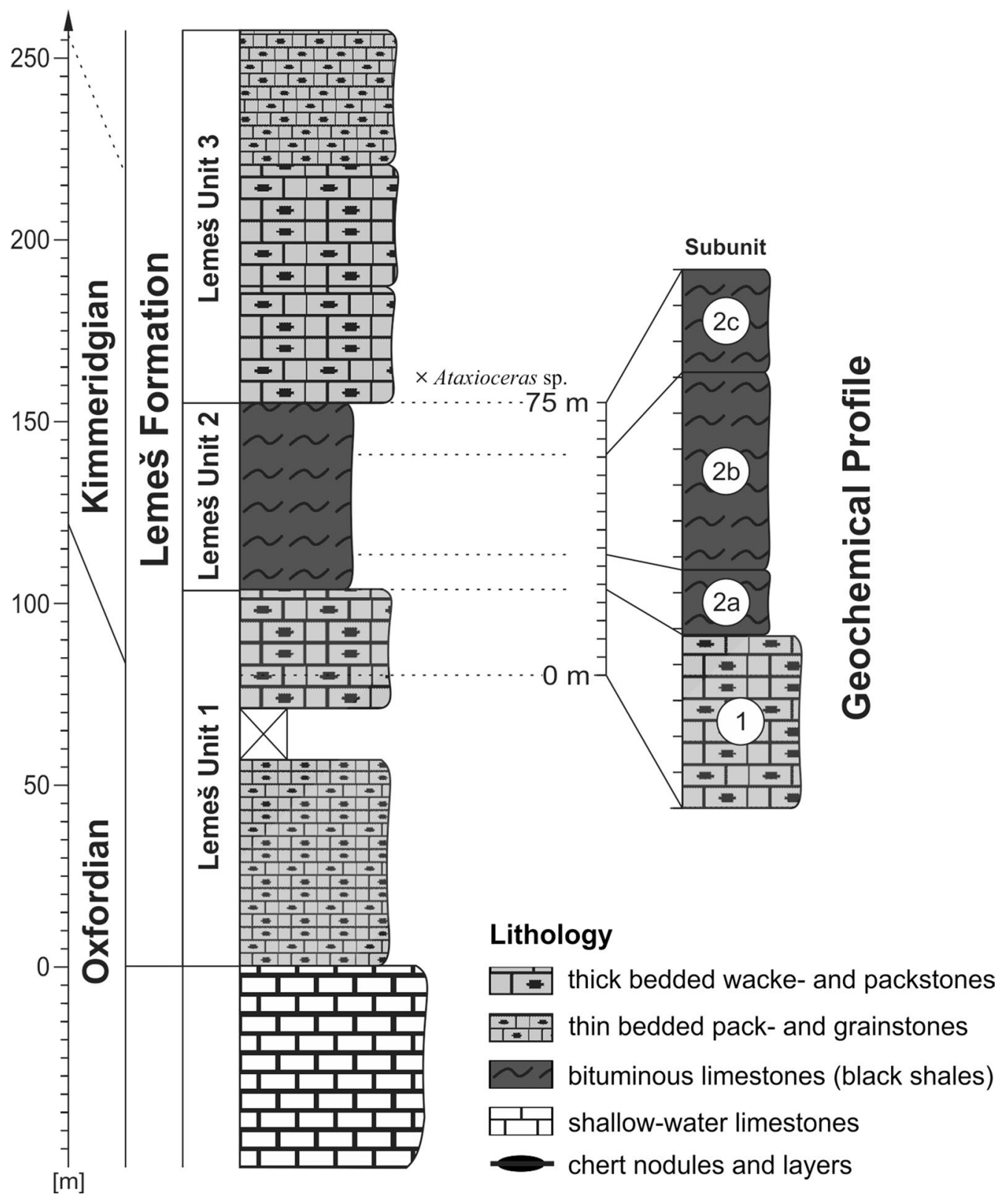

Fig. 3 Lithological column of the Lemeš Formation in the investigated area and the macroscopic delineation of the suggested stratigraphic Units 1-3. The subdivision of Unit 2 (geochemical profile) is based on geochemical results

with a Köhnen-Willsch instrument (Radke et al. 1980). The saturated and aromatic hydrocarbon fractions were analysed with a gas chromatograph (GC) fitted with a $30 \mathrm{~m}$ DB-1 fused-silica capillary column (i.d. $0.25 \mathrm{~mm} ; 0.25 \mu \mathrm{m}$ film thickness) coupled to a Finnigan MAT GCQ ion trap mass spectrometer for a first sample set and with a $30 \mathrm{~m}$ DB-5MS fused-silica column (i.d. $0.25 \mathrm{~mm} ; 0.25 \mu \mathrm{m}$ film thickness) coupled to a Thermo Fischer IS dual-quadrupole mass spectrometer for a second set. The analysis was performed with helium carrier gas and a heating rate of $4{ }^{\circ} \mathrm{C} / \mathrm{min}$ between 70 and $300{ }^{\circ} \mathrm{C}$, and a final isothermal period of $15 \mathrm{~min}$. The scan range of the GC in the electron ionisation mode was set from $m / z$ 50-650 (0.7 s total scan time). Absolute concentrations normalized to TOC, and relative percentages of distinct saturated and aromatic compounds were identified from retention time in the total ion current chromatograms and calculated from peak areas in accordance to the internal standards (saturated HC: deuterated $n$-tetracosane, aromatic HC: 1,1'-binaphthyl) or by peak areas in the according mass chromatograms, corrected by response factors for the intensities of the fragment ion. 
Inorganic carbon $\left(\delta^{13} \mathrm{C}_{\text {carb }}\right)$ and oxygen isotope $\left(\delta^{18} \mathrm{O}_{\text {carb }}\right)$ ratios were carried out for 202 samples. Measurements were performed by adding $100 \% \mathrm{H}_{3} \mathrm{PO}_{4}$ to samples heated at $70{ }^{\circ} \mathrm{C}$ in an online system (Gasbench II with carbonate option). Analysis was performed using a Thermo Fisher DELTA V isotope ratio mass spectrometer (Delta V IRMS). The results were calibrated to the Vienna-Pee Dee Belemnite (VPDB) standard for $\delta^{13} \mathrm{C}_{\text {carb }}$ (+1.95\% to NBS19 reference material) and $\delta^{18} \mathrm{O}_{\text {carb }}(-2.20 \%$ to NBS19 reference material), with analytic reproducibility better than $0.2 \%$ o.

For organic carbon isotope $\left(\delta^{13} \mathrm{C}_{\text {org }}\right)$ analyses of organicrich limestones, the samples were weighed into tin foil shuttles and combusted in an excess of oxygen using an elemental analyser (Flash EA 1112) at $1020^{\circ} \mathrm{C}$. The resulting $\mathrm{CO}_{2}$, after separation by column chromatography, was analysed online by the DELTA V IRMS. The ${ }^{13} \mathrm{C} /{ }^{12} \mathrm{C}$ isotopic ratios of the sample $\mathrm{CO}_{2}$ were compared with a monitoring gas calibrated to the V-PDB standard using NBS-19 reference material. Reproducibility of the whole analysis is in a range of $0.1-0.2 \%$.

All isotope ratios are reported in the delta $(\delta)$ notation in parts per mil (\%o) in reference to the VPDB standard.

$\mathrm{X}$-ray diffraction (XRD) was performed by a Philips $\mathrm{X}^{\prime}$ Pert $^{3}$ diffractometer with ten hand-mortared bulk samples on a side and top filled mount with a sample thickness of $\sim 10 \mu \mathrm{m}$. The measurement was set from 2 to $70^{\circ} 2 \theta$. A rough qualitative analysis of diagenetic calcite $29.84^{\circ}$ and $31.24^{\circ} 2 \theta$, quartz $20.84^{\circ}$ and $36.54^{\circ} 2 \theta$, and clay minerals was established, and a semi-quantitative analysis was performed according to an intensity factor in counts per second per 100 percent after Schultz (1964).

Fifty-five thin sections and 12 polished blocks were analysed using a Leica transmitted light microscope for microfacies and a Leica MPV microscope for qualitative maceral analysis and vitrinite reflectance measurements. Both microfacies analysis (Flügel 2004) and reflectance measurements (Taylor et al. 1998) followed established procedures.

All analysis was performed at Montanuniversitaet Leoben. For standard deviation of different methods, see Agahayeva et al. (2021).

\section{Results}

\section{Lithology, microfacies, and mineralogy}

The Lemeš succession in the study area is composed of three different units, distinguished on the basis of their lithology, microfacies (Fig. 5), and mineralogy.

Lemeš Unit $1(0-104 \mathrm{~m})$ is dominated by brownish to light-greyish, thin-bedded (up to $15 \mathrm{~cm}$ ) wackestones and thick-bedded (up to $50 \mathrm{~cm}$ ) packstones with shallow-water debris, large benthic foraminifera, and shell fragments in the basal $60 \mathrm{~m}$. Strong bioturbation and absence of shedding features are evident within all samples. The samples are free of deep-marine assemblages (i.e., radiolarian and ammonoids) and have low OM contents. One sample shows accessory amounts of pyrite. The facies of this section is typical for intra-platform environments (Flügel 2004). Upsection, a transition to radiolarian-rich, thick-bedded (up to $50 \mathrm{~cm}$ ) pack- and wackestones, accompanied by ammonoids (Fig. 5f) and shell fragments is observed. The majority of the samples have better OM preservation compared to the basal packstones. Bioturbation is still prevalent. The radiolaria and ammonoid assemblages suggest a deep-marine setting (Flügel, 2004).

Lemeš Unit 2 (104-154 m) consists of dark-brown, organic- and radiolarian-rich, siliceous, turbiditic packstones, grainstones, and bioturbated wackestones with rare thinned-shelled organisms and ammonoid fragments. OM is dominantly bound to thin-bedded $(1-46 \mathrm{~cm})$ and laminated $(1-10 \mathrm{~mm})$ limestones consisting of fine-grained, low-density turbidites (Fig. 5c-e). OM is also found within larger bioclasts. The silicified parts of the succession are relatively poor in $\mathrm{OM}$ due to early diagenetic silicification. These organic matter-rich deposits are typical of restricted basins (Flügel 2004).

XRD analysis at the base of Unit 2 shows the presence of $100 \mathrm{wt} \%$ calcite in the lower layer and $81 \mathrm{wt} . \%$ quartz and 19 wt. \% calcite in the upper layer. Because clay minerals are below the detection limit, the nature of volcanic ashes could not be determined. Upsection, the mineral composition of the siliceous limestones is represented by $93-99 \mathrm{wt} . \%$ calcite and 1-7 wt.\% quartz. One sample shows a small ankerite peak, which could not be quantified.

Lemeš Unit 3 (154-257 m) displays crinoid- and foraminifera-rich, greyish, thin-bedded (up to $25 \mathrm{~cm}$ ) wackestones with gradually increasing shallow-water influence. Radiolaria and filaments are still present but are less abundant than in the underlying Unit 2. Moreover, the organic matter content is reduced. The onset of greater resediment input, calciturbidites, and increasing bioturbation is noted upsection. The facies is accompanied by more frequently preserved ammonoids. Ataxioceras sp. (Fig. 6) was found about $20 \mathrm{~m}$ above the base of Unit 3. Ataxioceratinae are specific for the lower Kimmeridgian Tethyan ammonite zone A. hypselocyclum (Atrops 1982; Moliner and Olóriz 2009, 2010; Wierzbowski 2017). Ataxioceras sp. is rare in the uppermost layers of the underlying $S$. platynota zone (Atrops 1982). Additionally, a Saccocoma Agassiz brachialia/arm element (Fig. 5b) typical for Late Jurassic strata (Lefeld and Radwanski 1960; Flügel 2004) was identified. This unit shows typical sedimentary and stratigraphic features of slope or toe of slope environments (Flügel 2004). In some samples, large pores are filled with migrated, lightgrey bituminous matter. 


\section{a}

\section{younger basin fill}

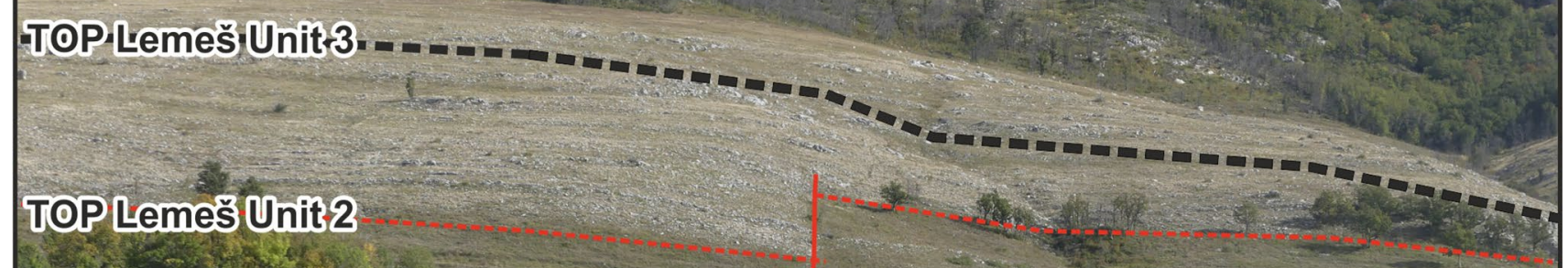

\section{TOPLemeš Unit 1}

TOP "Oxfordian Shallow Water"

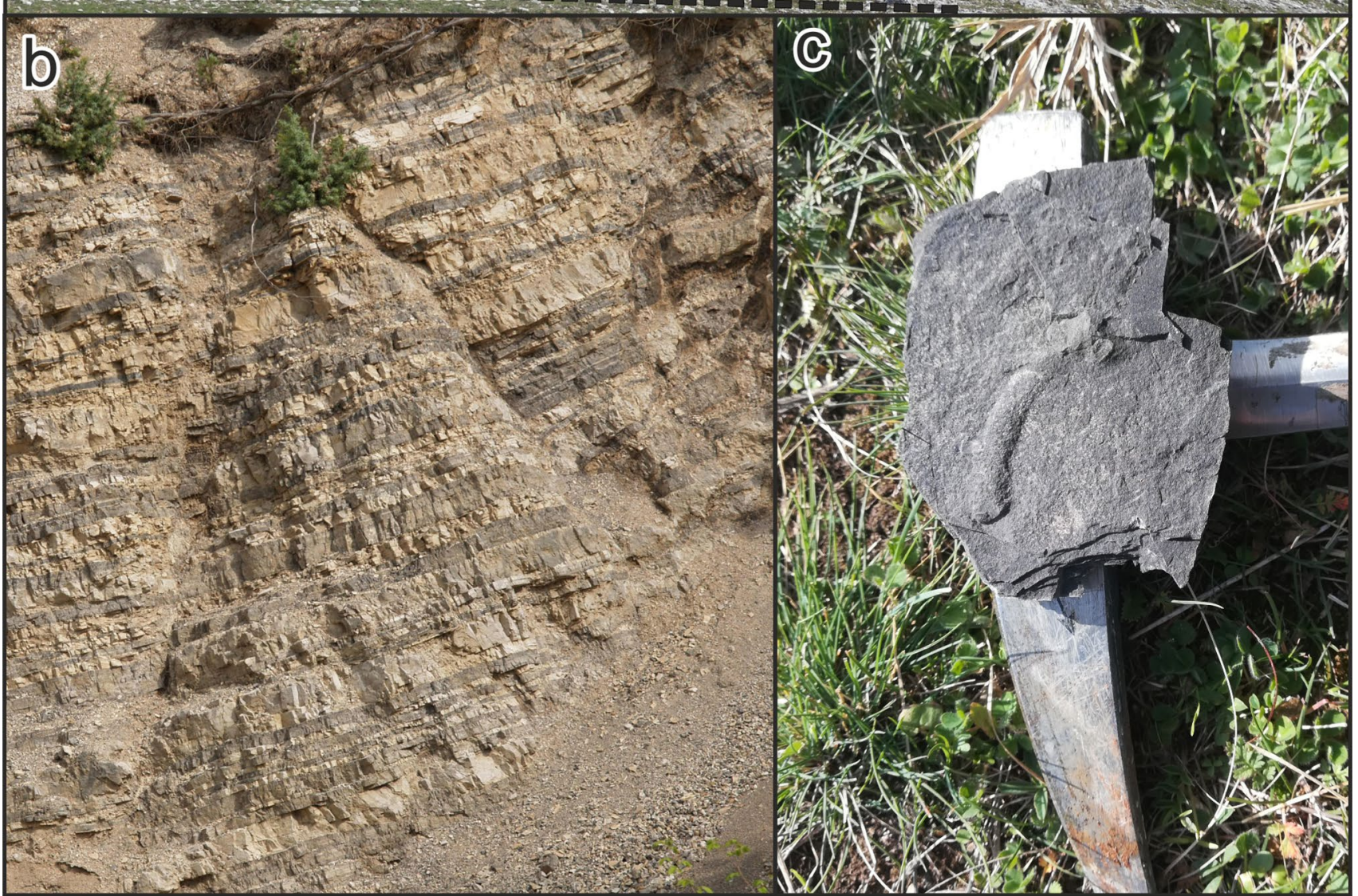


4Fig. 4 a Outcrop near Rastičevo, unit boundaries are indicated as well as a young fault, $\mathbf{b}$ intercalated bituminous limestone and siliceous organic-lean limestone of Unit 2, and $\mathbf{c}$ trace fossil (burrow) within Subunit 2a, showing that high-energy events may replace the anoxic conditions shortly and allow opportunistic species to invade

\section{Bulk geochemical parameters}

The vertical variation of geochemical parameters is shown in Fig. 7. The full geochemical dataset is presented in the Appendix. Initially, the geochemical data for siliceous limestone and bituminous limestone samples are presented separately. Afterwards, the vertical variation of parameters will be presented for each unit.

\section{Siliceous limestone}

Siliceous limestone samples typically contain very high calcite contents (avg. $\mathrm{Cc}_{\text {eq. }} 95.8$ wt.\%; Fig. 7a) and low amounts of organic matter (average TOC: $0.43 \mathrm{wt} . \%$; max. TOC: 1.1 wt.\%; Fig. 7b). HI values vary strongly (7-609 mg HC/g TOC; Fig. 7c). HI variations in organic-lean sediments are often either due to the mineral matrix effect (e.g., Langford and Blanc-Valleron 1990) or due to the presence of inert and reactive organic matter (e.g., Dahl et al. 2004) (Fig. 8).

A plot of Rock-Eval S2 versus TOC shows a good correlation $\left(r^{2}=0.95\right.$; Fig. $\left.9 \mathrm{a}\right)$. The slope of the regression line (5.39) and its $x$-intercept $(0.14$ wt.\%) determine either the true $\mathrm{HI}(539 \mathrm{mg} \mathrm{HC} / \mathrm{g}$ TOC) and the mineral matrix effect (e.g., Langford and Blanc-Valleron 1990) or the HI of the reactive organic matter and the amount of inert organic carbon (e.g., Dahl et al. 2004). In either case, Fig. 9a shows that the (reactive) organic matter is a hydrogen-rich type II kerogen. Sulphur content is very low in all samples (0.03-0.20 wt.\%, Fig. 7d). Consequently TOC/S ratios are relatively high (average 4.6, max 8; Fig. 7e), except the uppermost part of the succession. $T_{\max }$ values (average $426{ }^{\circ} \mathrm{C}$ ) indicate that the organic matter is immature. Within this context, PI values are surprisingly high (average: 0.19 ).

\section{Bituminous samples}

Bituminous samples consist of limestones with 75-98 wt.\% $\mathrm{Cc}_{\text {eq. }}$ and some mudstones, calcareous mudstones, and marlstones with $0.7-48.8 \mathrm{wt} . \% \mathrm{Cc}_{\text {eq. }}$ Average TOC contents (3.57 wt.\%) and $\mathrm{HI}$ values (502 $\mathrm{mg} \mathrm{HC} / \mathrm{g}$ TOC) are high. The slope and $x$-intercept of the regression line in the S2-TOC diagram (Fig. 9) show that the HI of the reactive organic matter (true HI) is $557 \mathrm{mg} \mathrm{HC} / \mathrm{g}$ TOC and the amount of inert organic carbon is $0.24 \mathrm{wt} . \%$. This indicates that there is no difference between the reactive organic matter of bituminous and siliceous limestone samples. Sulphur contents (average $0.60 \mathrm{wt} . \%$ ) are slightly higher than in siliceous limestone samples, but TOC/S ratios are in the same order (average 6.1, from $3.8-7.9$ ). Both, $T_{\max }$ (average $429{ }^{\circ} \mathrm{C}$ ) and PI values (average: 0.03 ) indicate low thermal maturity.

Unit 1 The uppermost $25 \mathrm{~m}$ of the Unit 1 have been included in the geochemical study. Siliceous limestones with low TOC contents $(0.15-0.95 \mathrm{wt} . \%)$ prevail in the studied interval with subordinate layers of bituminous limestone with relatively high TOC contents (max. 2.68 wt.\%).

Unit 2 Based on the geochemical parameters, three subunits were defined within the Lemeš Unit 2 (from base to top: Subunit $2 \mathrm{a}, 2 \mathrm{~b}$, and $2 \mathrm{c}$ ).

Subunit 2a (24.5-33.5 m) includes a high number of organic matter-rich rocks (bituminous limestones and some low-carbonate rocks) with TOC contents ranging from 1.22 to $12.63 \mathrm{wt} . \%$ and relatively high sulphur contents $(0.05-2.01 \mathrm{wt} . \%)$. HI values are very high as well (346-609 mg HC/g TOC), indicating the presence of type II kerogen. Siliceous limestone layers are rare. Consequently, average TOC content (4.60 wt.\%) of Subunit 2a is higher than that of any other unit. The strongly varying carbonate contents reflect the alternating lithotypes of this unit.

Subunit 2b (33.5-61.5 m) contains a high number of siliceous limestone layers. TOC contents of bituminous samples are generally more uniform and range from 1.09 to 5.88 wt. \%. The average TOC of Subunit $2 \mathrm{~b}$ is only $1.71 \mathrm{wt} . \%$ reflecting the high number of siliceous limestone layers.

Subunit 2c (61.5-75.5 m) contains more bituminous limestone layers than the underlying Subunit 2b, especially in the lower part. The TOC content of the organic-rich layers is similar to that in Subunit 2b (0.71-6.31 wt.\%; avg.: 1.98 wt.\%). TOC/S ratios of siliceous limestone layers show an upward decrease from values above 5 to values in the order of 0.94. In contrast, TOC/S ratios of bituminous limestone layers show an opposite trend and increase from 5.0 to 7.6.

\section{Organic petrology}

Representative photographs of polished blocks from Units 1 and 2 are shown in Figs. 10 and 11. Rocks in the upper part of Unit 1 contain small amounts of organic matter dominated by detrovitrinite and inertodetrinite (Fig. 10). Pyrofusinite is present in very low amounts (Fig. 10a).

Organic matter in the bituminous limestones of Subunit 2a is dominated by lamalginite, and contains minor amounts of telalginite and inertodetrinite (Fig. 11d,e). Fusinite and accessory detrovitrinite are also present. Organic matter in Subunit $2 \mathrm{~b}$ is also dominated by lamalginite, but shows increased amounts of detrital vitrinite and inertinite 

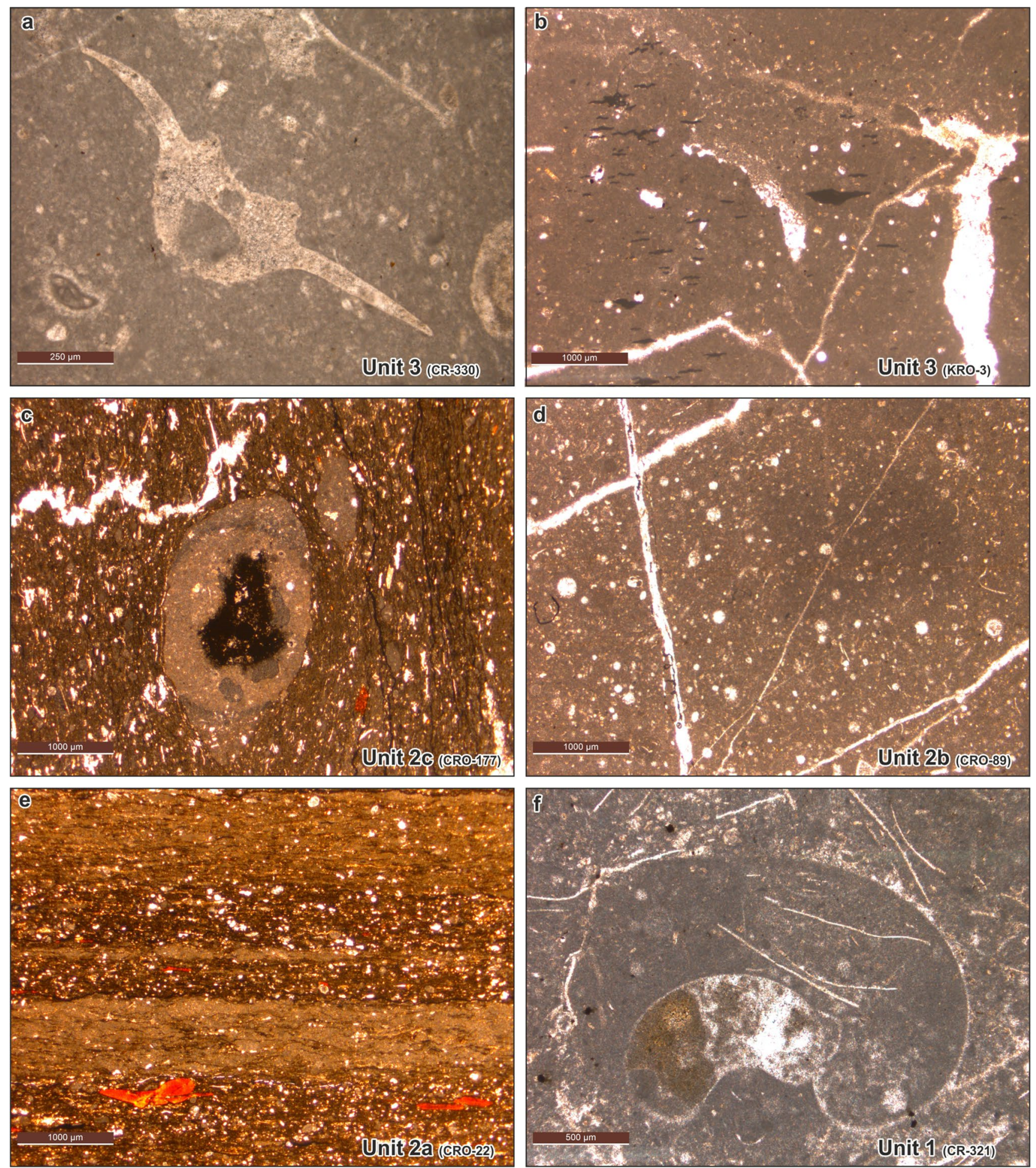

Fig. 5 a Bioturbated wackestone with crinoids, brachialia of Saccocoma Agassiz, foraminifera, and carbonate clasts, b bioturbated wackestone with few recrystallized radiolarians (lower part) and peloidal packstone (upper right) from the basal part of Unit 3, c bioturbated radiolaria wackestone with organic-rich layers and a concre-

tion filled with organic matter, $\mathbf{d}$ bioturbated radiolarian wackestone with rare thin shells, e laminated radiolaria wacke- to packstone with bigger OM components, and f packstone with ammonoid shell and shell fragments 


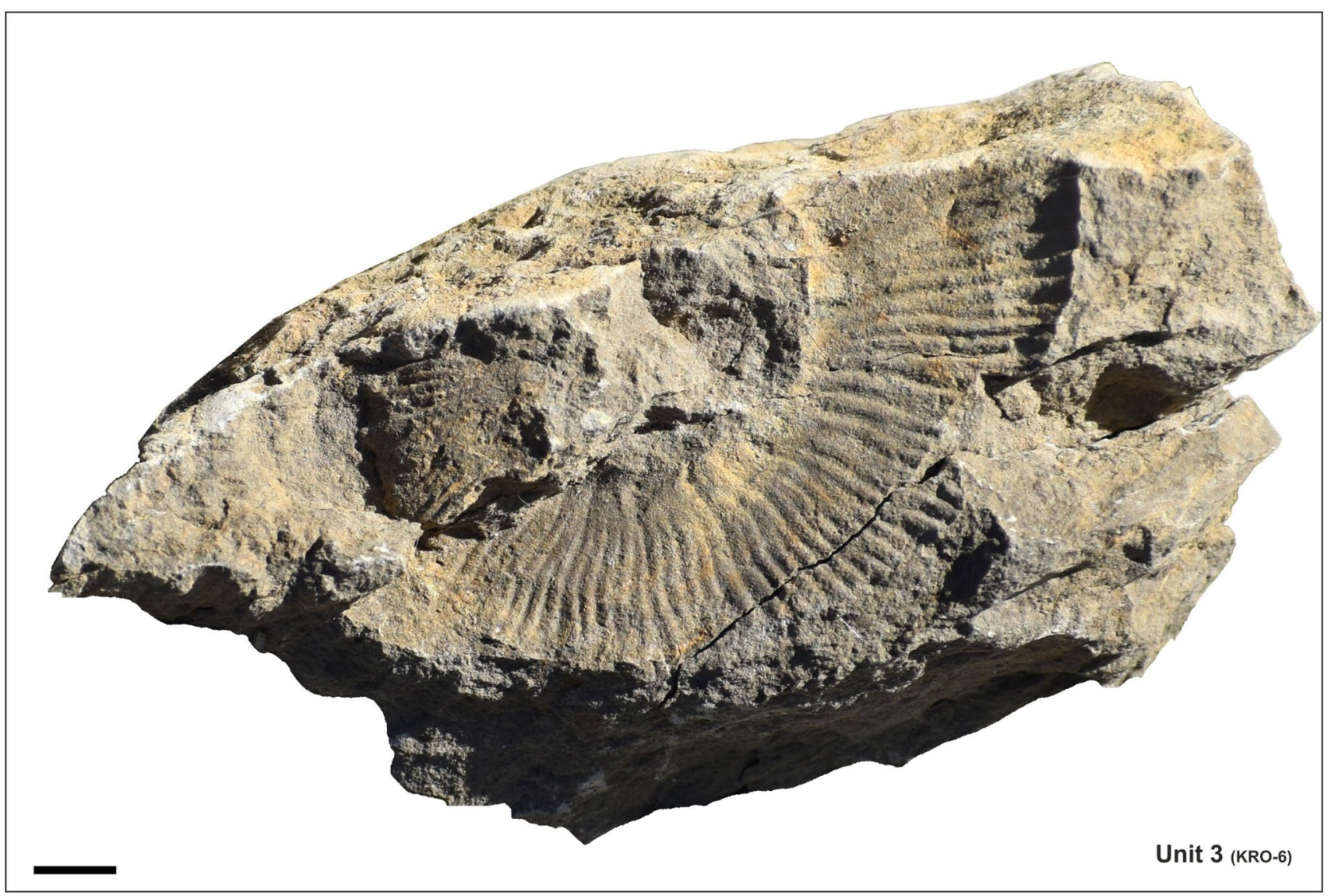

Fig. 6 Ataxioceras sp. dated to the lower Kimmeridgian A. hypselocyclum zone from the lowermost part of Unit 3

(Fig. 11c). Organic matter in the upper Subunit 2c contains high amounts of lamalginite and telalginite (Fig. 11a, b), and also has greater amounts of terrestrial macerals (dominant fusinite and subordinate detrovitrinite). All Lemeš Unit 2 samples include small amounts of micropyrite (diameter: 2-8 $\mu \mathrm{m})$ crystals, which do not show any signs of weathering (e.g., Fig. 11a-c).

Apart from primary macerals, small amounts of secondary bitumen are noticed along joints, in pores and parallel to lamalginite layers in Unit 2 samples (e.g., Fig. 11a-c, e). All samples show strong background fluorescence. This may result from a high amount of amorphous OM.

Vitrinite reflectance measurements were difficult because of the low amount of vitrinite, its often very small size, and the presence of bituminite. Moreover, vitrinite reflectance may be reduced in liptinite-rich samples (e.g., Peters et al. 2018). Vitrinite reflectance of samples Cro 40 $(0.39 \pm 0.06 ; n=36)$, Cro $93(0.47 \pm 0.07 ; n=21)$, and Cro $223(0.52 \pm 0.08 ; n=29)$ vary significantly, and have a high standard deviation. Particles interpreted as secondary bitumen show reflectance values between 0.28 and $0.38 \%$.

\section{Stable isotope composition of carbonate minerals and organic matter}

The vertical trend of stable carbon $\left(\delta{ }^{13} \mathrm{C}\right)$ and oxygen $(\delta$ ${ }^{18} \mathrm{O}$ ) isotope ratios of bulk carbonate and the carbon isotope ratio of organic matter are presented in Fig. 12.

Stable carbon isotope ratios of carbonate minerals $\left(\delta^{13} \mathrm{C}_{\text {carb }}\right)$ range from -1.36 to $+3.50 \%$ VPDB. They are typically lower in siliceous limestone samples than in bituminous limestone samples. The highest differences (up to $1.5 \%$ ) are observed in Subunit 2a and the lower part of Subunit $2 b$, as well as near the border between subunits $2 b$ and $2 c$. Despite these differences, the vertical trend of both lithotypes is similar. The upper part of Unit 1 shows an upward decrease in $\delta^{13} \mathrm{C}_{\text {carb }}$ values (3.50-1.76\% VPDB) independent of lithology. Subunit $2 \mathrm{a}$ is characterized by the lowermost $\delta^{13} \mathrm{C}_{\text {carb }}$ values, which is especially valid for siliceous limestone, which show negative and relative uniform values ( -0.17 to $-1.36 \%$ VPDB). In contrast, values from laminated limestones are strongly oscillating (1.59 to $-1.18 \%$ VPDB). Subunit $2 b$ has low values in the lower 


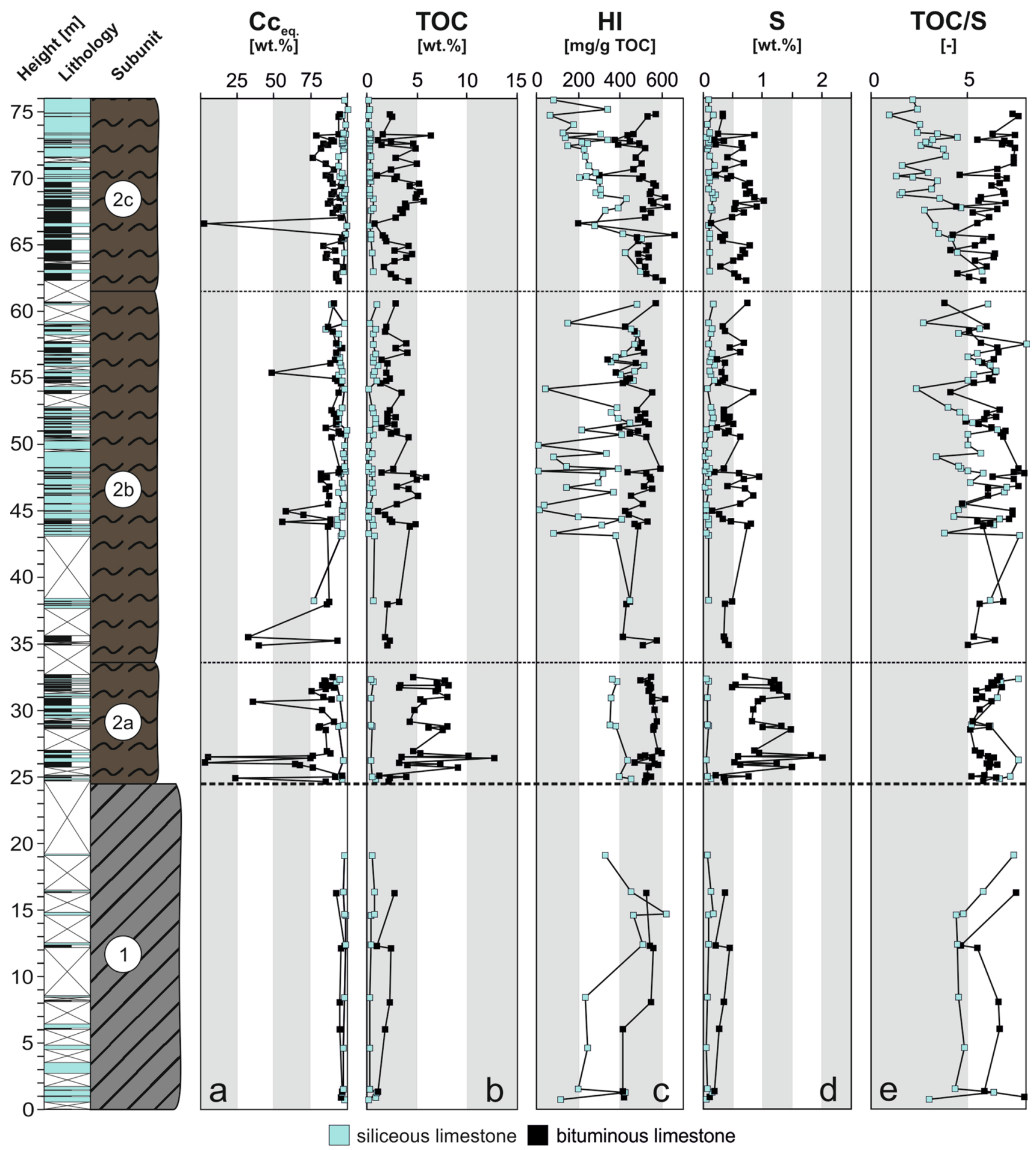

Fig. 7 Vertical plots of bulk geochemical parameters: $\mathbf{a ~ C c}_{\text {eq. }}$ (calcite equivalent percentages), b TOC (total organic carbon), $\mathbf{c}$ HI (hydrogen index). wt.\% weight percent, $\mathbf{d ~ S}$ (sulphur) content, and e TOC/S

and upper part (minimum: $-0.66 \%$ VPDB) and higher values in the middle part (maximum: $2.13 \%$ VPDB). Subunit $2 \mathrm{c}$ starts with low $\delta^{13} \mathrm{C}_{\text {carb }}$ values and shows an increasing upward trend ( -0.48 to $2.43 \%$ VPDB). Similar ratio; the defined units and the lithotypes within the profile are indicated on the left

values for both lithotypes are observed in the upper part of Subunit 2c.

In contrast to $\delta^{13} \mathrm{C}_{\text {carb }}, \delta^{18} \mathrm{O}_{\text {carb }}$ values are relatively uniform ( -4.18 to $-1.70 \%$ VPDB). Moreover, with the 


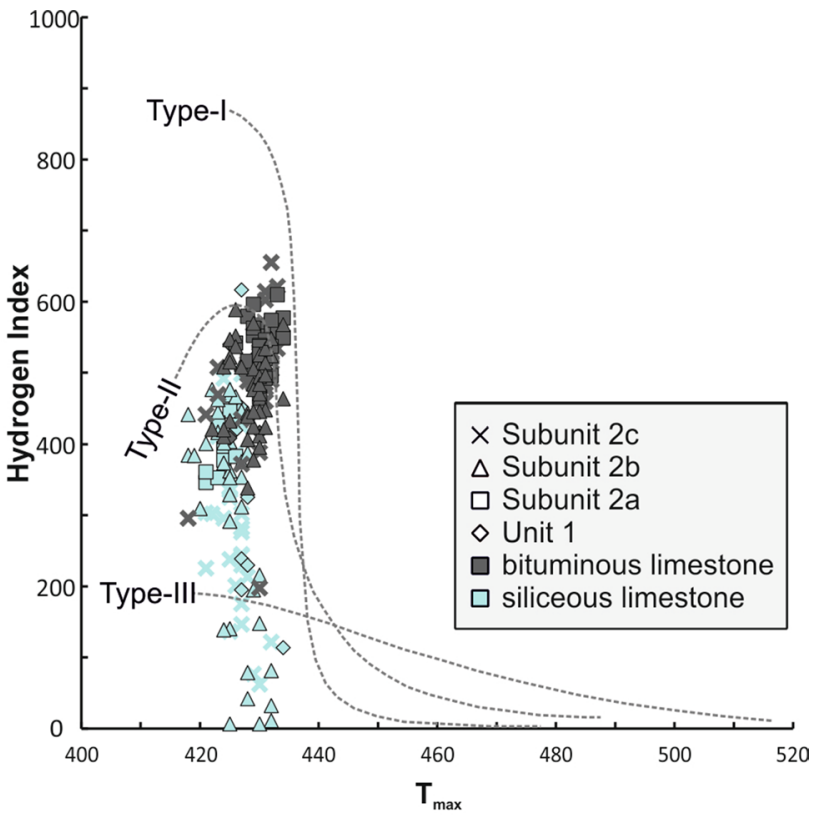

Fig. 8 Cross-plot of HI vs. $T_{\max }$ after Espitalié et al. (1984)

exception of Subunit $2 \mathrm{c}$, where $\delta^{18} \mathrm{O}_{\text {carb }}$ values in siliceous limestones are less negative that in bituminous limestones, differences between values from both lithotypes are minor. Two negative outliers are observed in bituminous samples in the lower part of Subunit 2a.

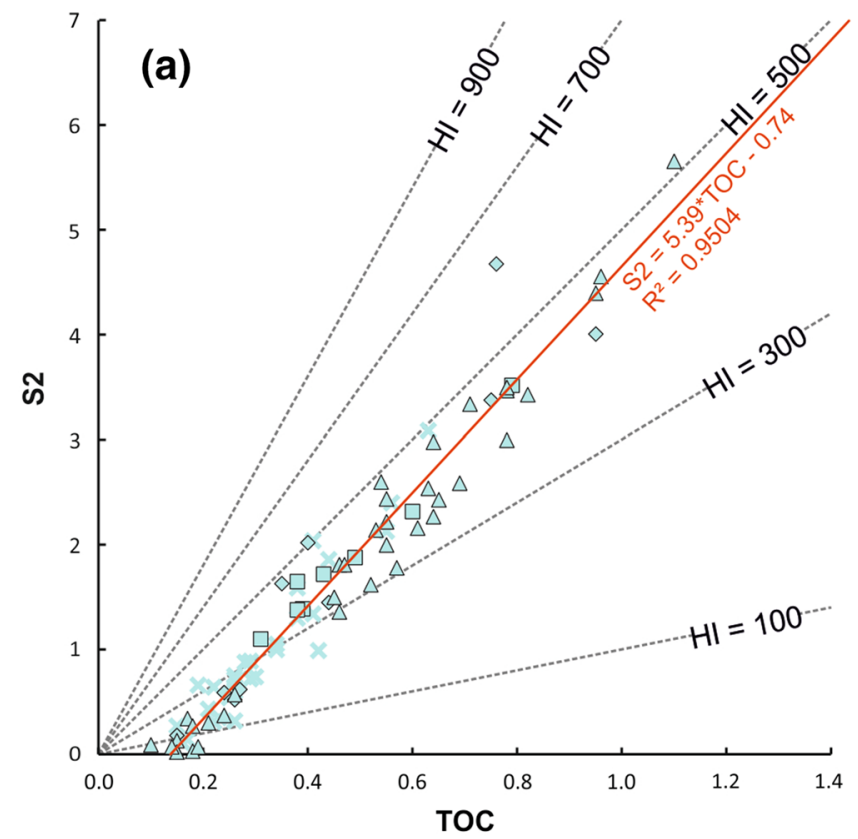

Fig. 9 Cross-plots of S2 vs. TOC after Espitalié et al. (1984) with regression lines for a siliceous limestones, and $\mathbf{b}$. bituminous limestones. The slopes of the regression lines (5.29 and 5.58) show that
Organic carbon isotope values $\left(\delta^{13} \mathrm{C}_{\text {org }}\right)$ of Unit 1 are consistently high ( -26.50 to $-26.20 \%$ o VPDB). The basal bituminous layer of Subunit $2 \mathrm{a}$ shows the minimum $\delta^{13} \mathrm{C}_{\text {org }}$ value $\left(-29.90 \%\right.$ VPDB) as well as the minimum $\delta^{13} \mathrm{C}_{\text {carb }}$ value. Above the minimum, an abrupt increase in $\delta^{13} \mathrm{C}_{\text {org }}$ values is visible with high values often between -27.00 and $-26.00 \%$ VPDB. This interval is followed by more negative $\delta^{13} \mathrm{C}_{\text {org }}$ values ( -28.20 to $-27.00 \%$ VPDB). $\delta^{13} \mathrm{C}_{\text {org }}$ values near the base of Subunit $2 \mathrm{~b}$ are low $(\leq-28.00 \%$ ), but the main part of Subunit $2 b$ is characterized by a decreasing upward trend from -27.0 to $-28.4 \%$. Subunit $2 \mathrm{c}$ is characterized by rather uniform $\delta^{13} \mathrm{C}_{\text {org }}$ values $(-28.50$ to $-27.70 \%$ VPDB).

\section{Molecular composition of hydrocarbons}

The full data set of absolute concentrations and derived ratios (Fig. 13) are presented in the Appendix. The $n$-alkane distributions are characterized by high amounts of shortchain (avg.: $\left.\sum n-\mathrm{C}_{15-20} / \sum n-\mathrm{C}_{15-35}=0.41\right)$ and mid-chain $n$-alkanes (avg.: $n$ - $\mathrm{C}_{21-25} / \sum n-\mathrm{C}_{15-35}=0.36$ ), whereas longchain $n$-alkanes typically occur in lower concentrations (avg. $\sum n-\mathrm{C}_{26-32} / \sum n-\mathrm{C}_{15-35}=0.22$ ). However, long-chain $n$-alkanes dominate in one sample from Subunit 2c (0.75). The carbon preference index (CPI; as defined by Bray and Evans 1961) varies in the narrow range from 1.09 to 1.45.

The ratio of the acyclic isoprenoids pristane $(\mathrm{Pr})$ and phytane $(\mathrm{Ph})$ is very low in Unit $1(\leq 0.2)$ and higher, as well as

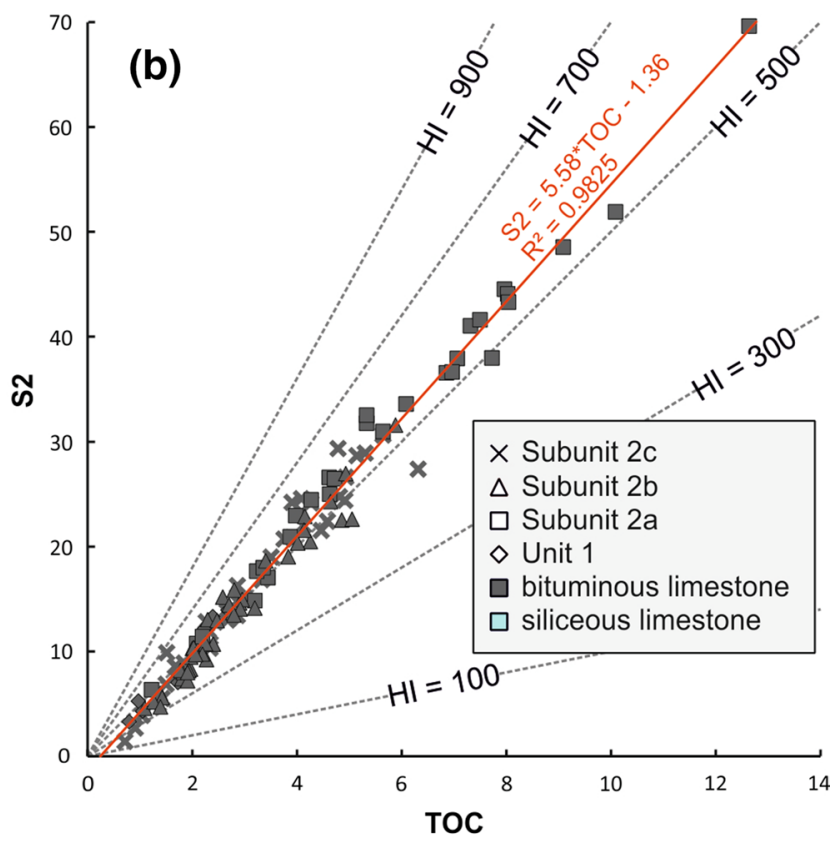

both siliceous and bituminous limestones contain hydrogen-rich organic matter with HI values in the order of $550 \mathrm{mg} \mathrm{HC} / \mathrm{g}$ TOC 

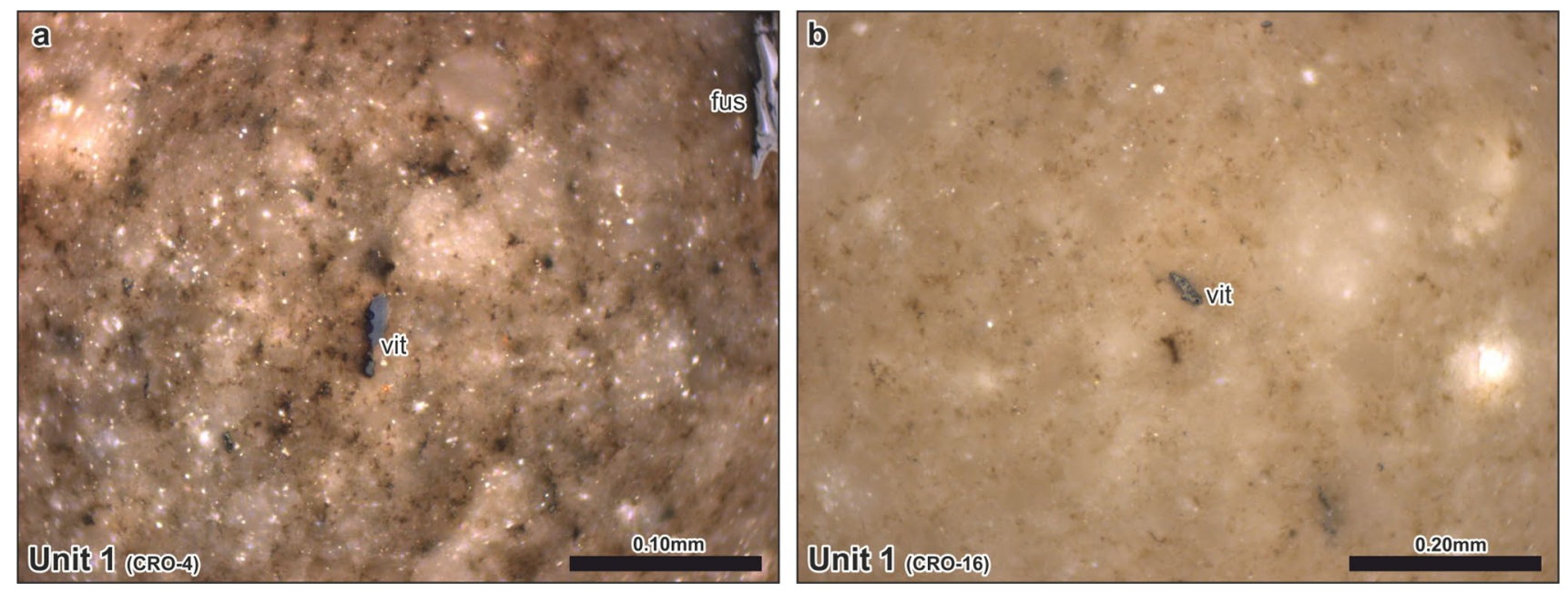

Fig. 10 Reflected white light microphotographs from a, b Lemeš Unit 1. vit vitrinite, fus fusinite

more variable, in Subunit 2a (0.35-1.33). In Subunit 2b, Pr/ $\mathrm{Ph}$ ratios decrease upwards from 0.96 to 0.20 . Variable, but generally small ratios $(0.17-0.61)$ are observed in Subunit $2 \mathrm{c}$.

$\mathrm{C}_{16}-\mathrm{C}_{18}$ aryl isoprenoids were detected in low amounts in all samples (0.1-4.1 $\mu \mathrm{g} / \mathrm{g}$ TOC). Some samples also contain $\mathrm{C}_{14}-\mathrm{C}_{21}$ aryl isoprenoids. Concentrations of $\mathrm{C}_{16}-\mathrm{C}_{18}$ aryl isoprenoids tend to increase upwards, although some high values also occur in the Unit 1 and Subunit 2 a.

$\mathrm{C}_{29}$ steranes (30.8-52.5\%) are more abundant than $\mathrm{C}_{27}$ (25.0-39.2\%) and $\mathrm{C}_{28}$ steranes (20.4-39.5\%) (Fig. 15). The percentage of $\mathrm{C}_{29}$ steranes shows a subtle upward decrease. Hence, the difference between the amounts of $\mathrm{C}_{27}, \mathrm{C}_{28}$, and $\mathrm{C}_{29}$ steranes is relatively low in Subunit 2c.

Diasteranes and 4-methylsteranes are generally absent. $\mathrm{C}_{21}$-pregnane and $\mathrm{C}_{22}$-homopregnane are present in significant amounts (max. $19.61 \mu \mathrm{g} / \mathrm{g}$ TOC and $18.09 \mu \mathrm{g} / \mathrm{g}$ TOC, respectively), but do not show any stratigraphic trend. Norcholestane (up to $1.02 \mu \mathrm{g} / \mathrm{g}$ TOC) has only been observed in some samples. Monoaromatic steroids (MAS) are present in all samples (up to $46.64 \mu \mathrm{g} / \mathrm{g}$ TOC), whereas triaromatic steroids (TAS) occur in small concentrations and are absent in many samples. The $\alpha \alpha \alpha-\mathrm{C}_{29}$ sterane $20 S /(20 S+20 R)$ isomerization ratios (average: 0.49 ) are slightly below the equilibrium value 0.54 . Relatively low isomerization ratios are observed in Subunit $2 \mathrm{a}$. The $\alpha \alpha \alpha /(\alpha \alpha \alpha / \alpha \beta \beta) \mathrm{C}_{29}$ steranes ratio is high (0.52-0.73).

The steranes/hopanes ratios are low (0.14-0.56; average: 0.27). In Subunit $2 b$, the steranes/hopanes ratio decreases upwards, whereas an increasing upward trend is observed in Unit 2c (Fig. 13). Similar to the sterane isomerization ratio, the $\alpha \beta-\mathrm{C}_{32}$ hopane $22 S /(22 S+22 R)$ isomerization ratios are close to the equilibrium value of 0.61 (average 0.58 ).
Gammacerane is absent. The maximum concentration of 28,30-bisnorhopane is $39.06 \mu \mathrm{g} / \mathrm{g}$ TOC, but most samples contain low amounts. Benzohopanes (max. $28.09 \mu \mathrm{g} / \mathrm{g}$ TOC) and $\mathrm{C}_{31}$-hopene (max. $23.53 \mu \mathrm{g} / \mathrm{g}$ TOC) are found in some samples only. The ratios of $\mathrm{C}_{28}-18 \alpha$-Trisnorneohopane (Ts) and $\mathrm{C}_{27}-17 \alpha$-Trisnorhopane (Tm) are very low (avg. 0.06), even though Subunit $2 \mathrm{a}$ and Subunit $2 \mathrm{~b}$ show values up to 0.18 (Fig. 13).

The methylphenanthrene index (MPI-1) (Radke and Welte 1981) could be determined for some samples and ranges from 0.30 to 0.49 , with a single exception (0.67). A slight upward decrease is observed. Dibenzothiophenes (DBT) are recorded in all samples in significant amounts. In contrast, phenanthrenes $(\mathrm{Ph})$ occur generally in low concentrations and could not be quantified in all samples. Consequently, $\mathrm{DBT} / \mathrm{Ph}$ ratio are very high, especially in Unit 2 samples. Samples with high concentrations of methyldibenzothiophenes show methyldibenzothiphene ratios (MDR) (Radke 1988) between 0.60 and 1.12 (average 0.88). Alkylbenzenes are noted in some samples with concentrations up to $66.31 \mu \mathrm{g} / \mathrm{g}$ TOC.

The gymnosperm specific biomarkers bis-nor-abietatriene (max. $2.48 \mu \mathrm{g} / \mathrm{g}$ TOC) and nor-abietatriene $(\max .1 .91 \mu \mathrm{g} / \mathrm{g}$ TOC) are found in some samples from Unit 2.

\section{Discussion}

\section{Stratigraphic evolution}

The first appearance of open-marine organisms (i.e., radiolarians, filaments, and ammonites) is recorded in Unit 1 (Fig. 14) above Oxfordian shallow-water limestones. These Oxfordian shallow-water deposits, dated by foraminifera 
Fig. 11 Reflected white light (left) and fluorescence mode (right) microphotographs from Lemeš Subunits $2 \mathrm{c}(\mathbf{a}, \mathbf{b}), 2 \mathrm{~b}$ (c), and 2a (d, e). lam lamalginite, tel telalginite, vit vitrinite, in inertinite, py pyrite, bit secondary bitumen, fus fusinite
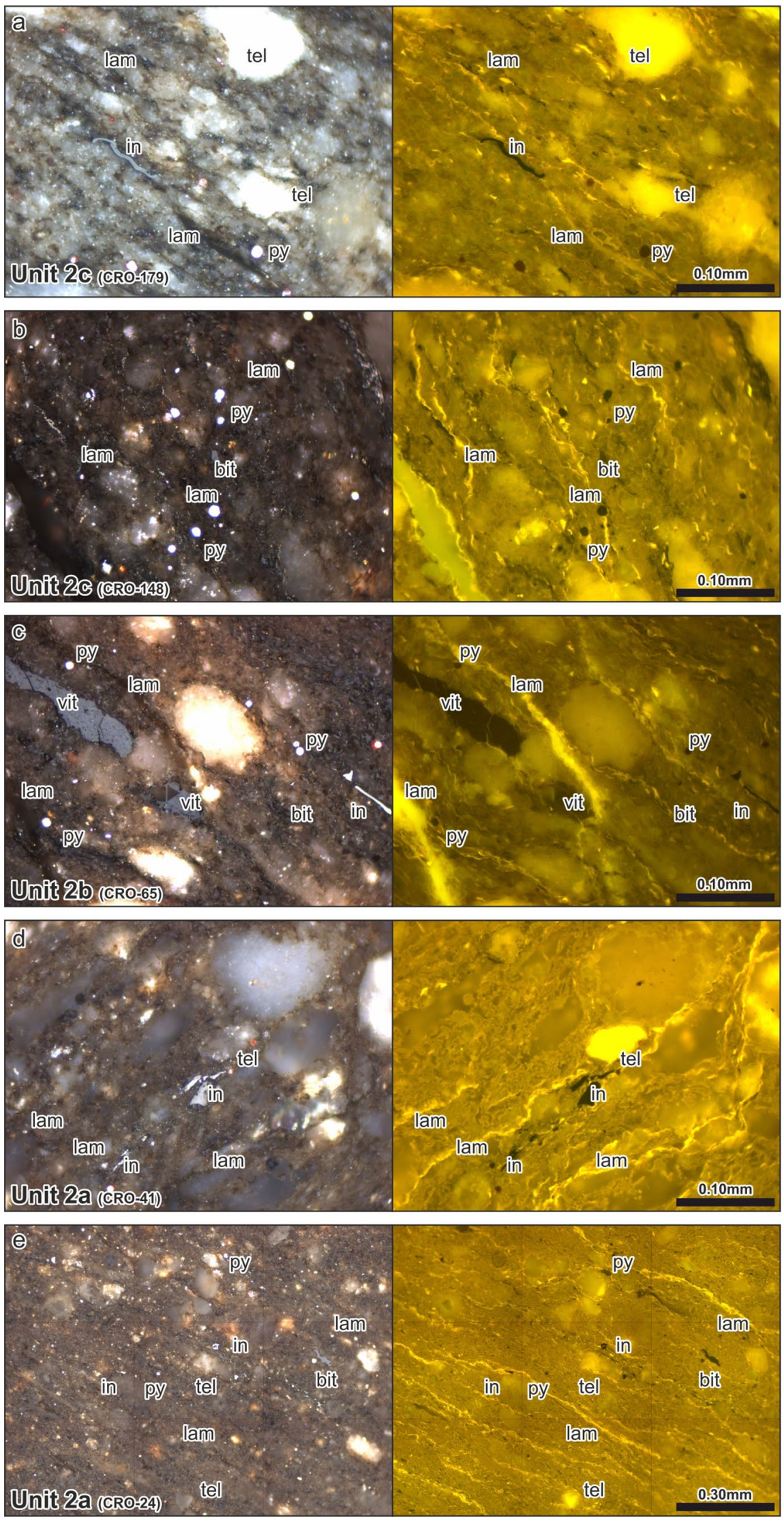


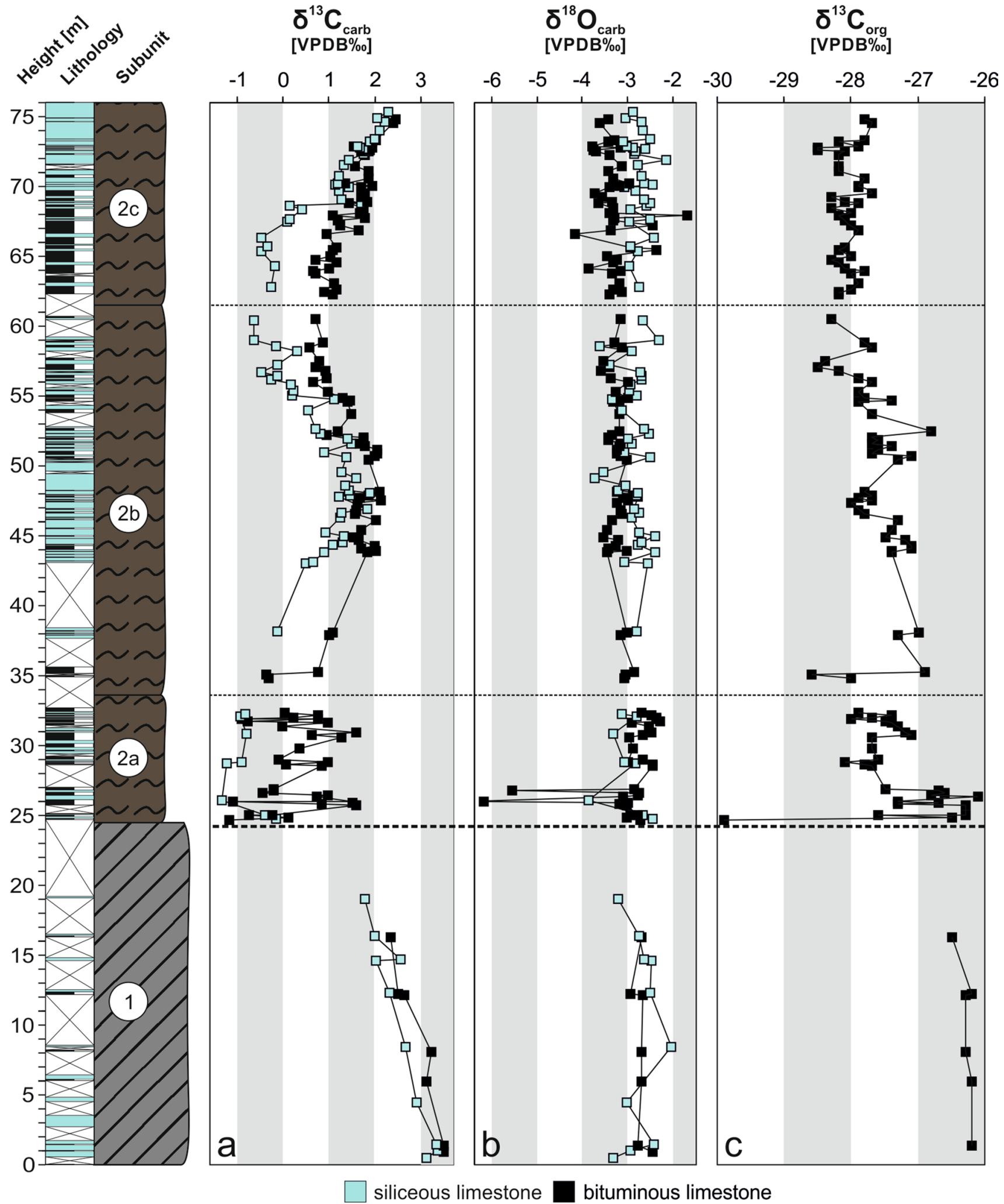

Fig. 12 Vertical variations of a the inorganic carbon isotope composition $\left(\delta^{13} \mathrm{C}_{\mathrm{carb}}\right.$; VPDB), $\mathbf{b}$ the oxygen isotope composition $\left(\delta^{18} \mathrm{O}_{\text {carb }}\right.$; VPDB) of carbonate minerals, and $\mathbf{c}$ the isotope composition of organic matter $\left(\delta^{13} \mathrm{C}_{\text {org }}\right.$; VPDB) of bituminous limestone samples. The defined units and the lithotypes within the profile are indicated on the left 

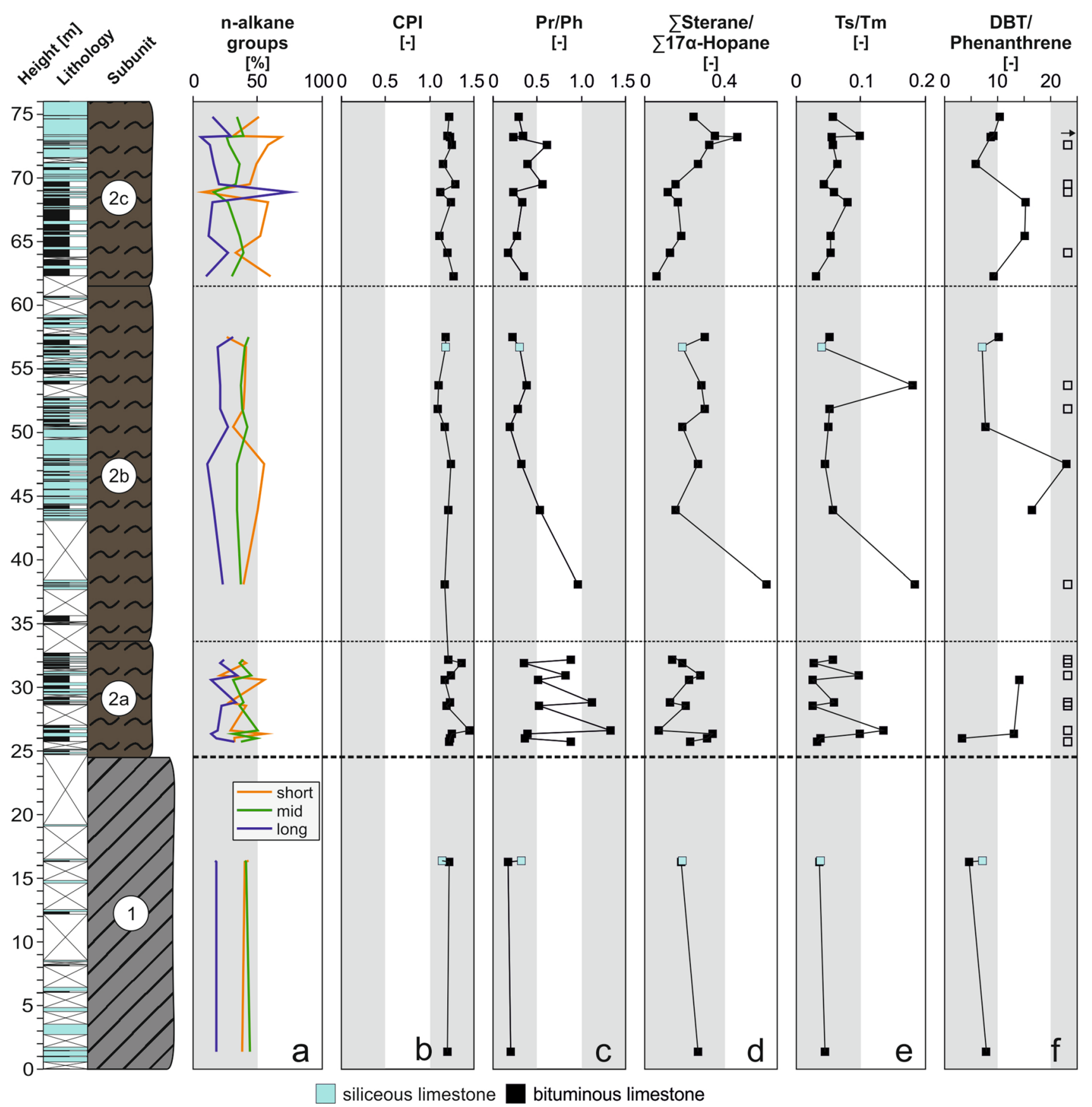

Fig. 13 Vertical variations of a $n$-alkane distribution of short-, mid-, and long-chain $n$-alkanes, b CPI carbon preference index, c pristane/phytane $(\mathrm{Pr} / \mathrm{Ph})$ ratio, d $\Sigma$ sterane/ $\Sigma 17$-hopane ratio, e $\mathrm{C}_{28}$-18 $\alpha$-trisnorneohopane/ $\mathrm{C}_{27}-17 \alpha$-trisnorhopane $(\mathrm{Ts} / \mathrm{Tm})$ ratio, and f dibenzothiophene (DBT)/phenanthrene ratio (empty squares indicate samples with high concentrations of dibenzothiophene, but no phenanthrene). The defined units and the lithotypes within the profile are indicated on the left
(Velić 2007), are of lagoonal facies with diverse benthic organisms, strong bioturbation, and relatively high micritic carbonate production (Dragičević and Velić 1994; Velić et al. 1994, 2002a; Tišljar et al. 1994).

The radiolarian packstones of this microfacies contain components derived from shallow-water environments, which, as seen in the type region (Furlani 1910), must have been within the proximity of the Lemeš Basin. Furthermore, evidence for nearby vegetated land is given by the occurrence of gymnosperm biomarkers and vitrinite particles in Unit 2. Unit 1 records the first accumulation of high amounts of OM (and sparse pyrite), which is probably due to periodically decreasing oxygen contents within the basin. The changes within Unit 1 reflect rapid rise of relative sea level 


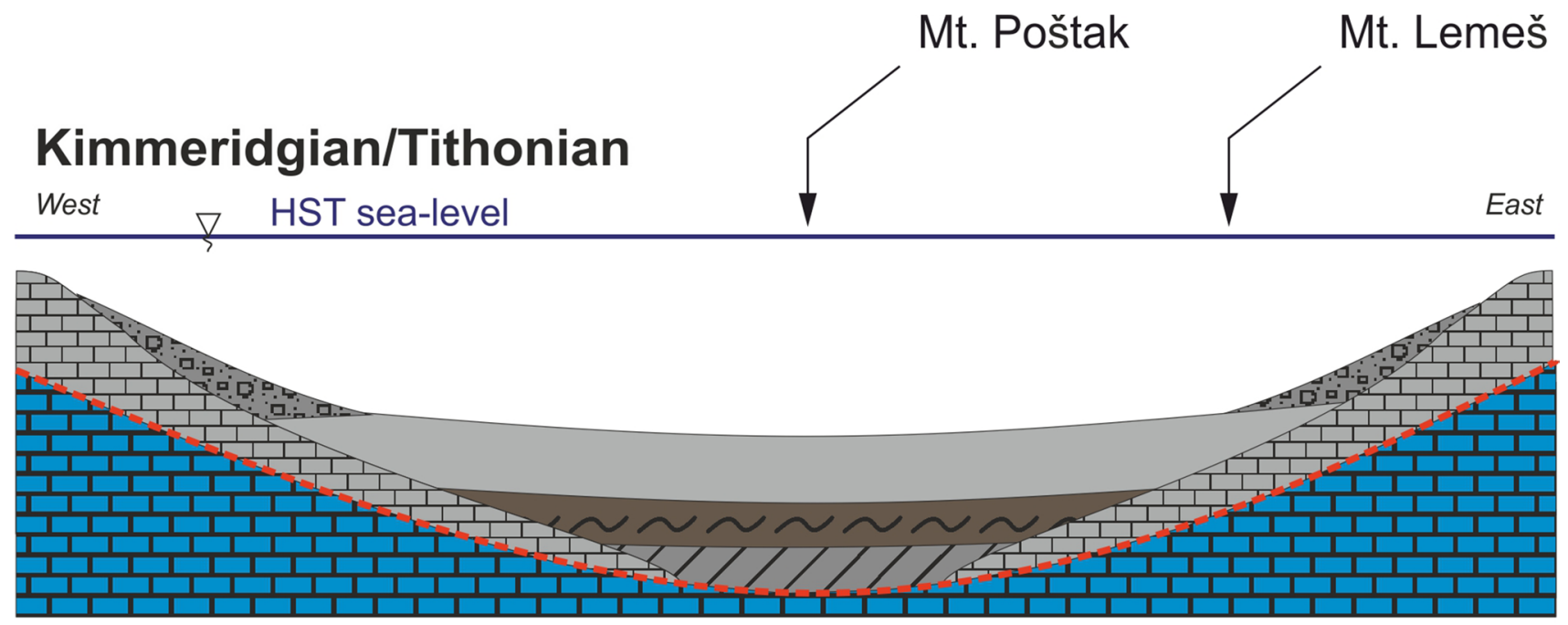

\section{Earliest Kimmeridgian}

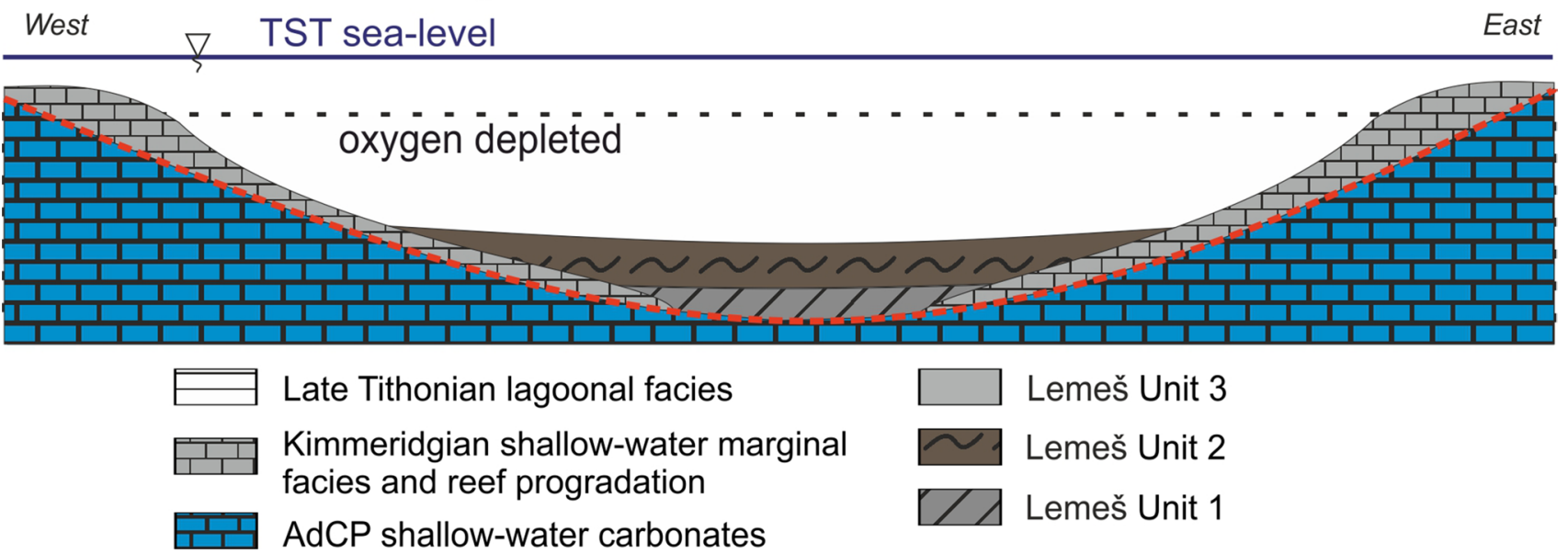

Fig. 14 The depositional evolution of the Lemeš Basin, tectonically controlled in the uppermost Oxfordian and eustatic driven from the Kimmeridgian transgressive system tract (TST) and Kimmeridgian-to-Tithonian highstand system tract (HST)

due to increasing subsidence. The shallow-water organisms at that time were no longer able to counterbalance the newly created accommodation space by carbonate production. Hence, shallow-marine carbonates were restricted to the rims of the newly formed basin (Furlani 1910). The basin received little carbonate material from these shallow-water areas and became periodically restricted near the bottom.

The transition to Unit 2 is marked by a change to organicrich bituminous limestones intercalated into often-laminated, siliceous limestones. This transition could be related to a volcanic event at the base of Unit 2 (Blažeković Smojić et al. 2009). The organic-rich Unit 2 consists of radiolarian wacke- and packstones with high organic matter content. Most of the samples are non-bioturbated and their depositional structures, organic-rich layers, and pyrite are well preserved. These are indications for a further decrease of the free oxygen, and the evolution of an anoxic depositional environment, which was likely due to water column stratification. The sedimentary structures indicate deposition below the fair-weather wave base. However, rare trace fossils in organic-rich bituminous limestones in Subunit 2a (Fig. 4c) indicate at least periodical open basin conditions with increased oxygen.

An abrupt decrease in preserved organic matter is noted in Unit 3, accompanied by a more open-marine microfacies and more oxygenated depositional conditions. This transition is dated by Ataxioceras sp. to the early Kimmeridgian Hypselocyclum zone (Moliner and Olóriz 2010), which 


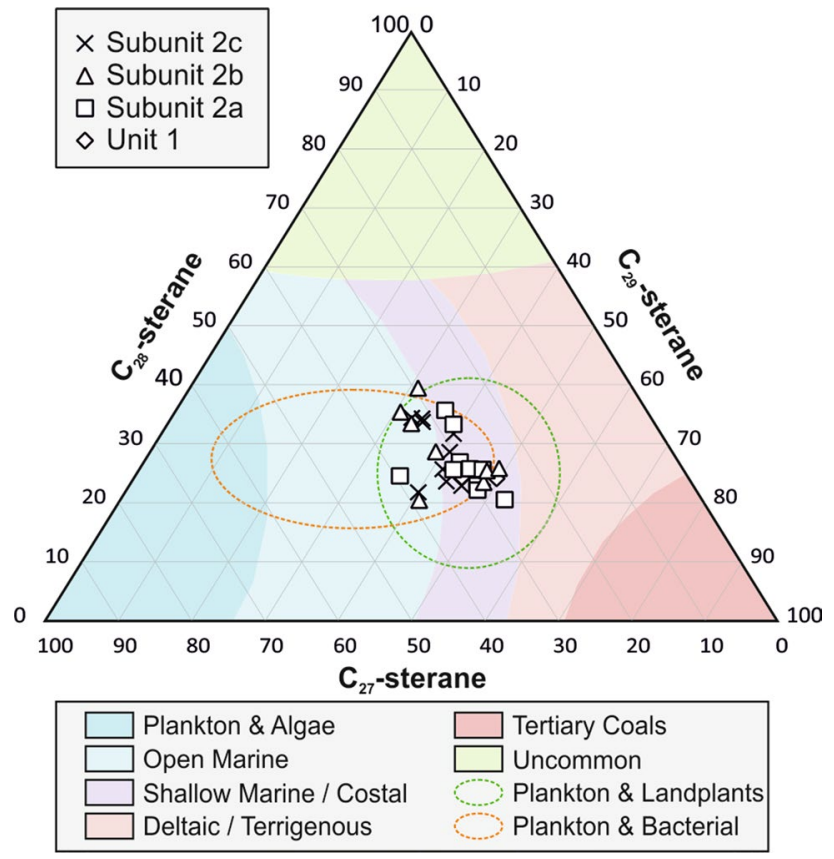

Fig. 15 Ternary plot of relative proportions of $\mathrm{C}_{27}, \mathrm{C}_{28}$, and $\mathrm{C}_{29}$-steranes

agrees with the presence of Saccocoma AgAssiz indicating a Kimmeridgian-to-early Tithonian age. The decrease in organic matter, ammonite fragments and radiolarians, and an increase in shallow-water carbonate components, accompanied by a crinoid and foraminifera fauna, reflect a change in the depositional environment with increased shallow-water carbonate production near the rims of the basin. Enhanced shedding of shallow-water carbonates resulted in a shallowing of the basin and more oxygenated conditions. However, a connection to a deep-marine realm must have existed during the early phase of the deposition of Lemeš Unit 3, which served as migration pathway for ammonites and radiolarians.

\section{Source of organic matter and its amount}

Despite varying HI values in siliceous limestone samples (Fig. 8), reconstructions of true HI values (Langford and Blanc-Valleron 1990) or HI values of the reactive organic matter (Dahl et al. 2004) show that the organic matter in siliceous and bituminous limestone samples is similar and contains high HI values ( $550 \mathrm{mg} \mathrm{HC/g}$ TOC). This classifies the organic matter as hydrogen-rich type II kerogen.

This classification is in agreement with maceral composition, which is dominated by alginite and liptodetrinite (Fig. 11) derived from algal and bacterial biomass. Lamalginite reflects algal and microbial mats, whereas telalginite is typically derived from planktonic algae. Very low steranes/hopanes ratios (Fig. 13d) show that microbial biomass contributed significantly to the aquatic organic matter (Moldowan and Fago 1986; Thiel et al. 1999; Peters et al. 2005). High amounts of aquatic organic matter are also reflected by $n$-alkane distributions dominated by short- and mid-chain $n$-alkanes (Ficken et al. 2000; Fig. 13a).

Terrestrial macerals (vitrinite and inertinite) occur in minor amounts and are important only in samples with low TOC contents (e.g., in Unit 1; Fig. 10). Hence, percentages of long-chain $n$-alkanes and CPI values are low (Eglinton and Hamilton 1967; Fig. 13a, b). Despite low land plant input, relative proportions of $\mathrm{C}_{29}$-steranes are high (Fig. 15). This shows that land plants are not the only precursor of $\mathrm{C}_{29}$-steranes. Specific bacterial assemblages may contribute to $\mathrm{C}_{29}$-steranes (e.g., Moldowan et al. 1985; Volkman 1988; Affouri et al. 2013), especially in carbonate source rocks (e.g., Grantham 1986; Buchardt et al. 1989). Gymnospermderived biomarkers (nor-abietatriene, bis-nor-abietatriene) are present in only a few samples. Rare pyrofusinite may have a wind-blown origin.

HI values in Unit 2 show only minor variation (Fig. 7c). This indicates that the organic matter type is uniform and that preservation conditions did not vary. Hence, very high TOC content in Subunit 2a probably reflects increased bioproductivity. For samples with carbonate content exceeding $80 \mathrm{wt} \% \mathrm{Cc}_{\text {eq. }}$, there is a general negative relation between TOC and $\mathrm{Cc}_{\text {eq. }}\left(r^{2}=0.62\right)$, suggesting that apart from bioproductivity, organic matter richness is also controlled by dilution by carbonate minerals.

\section{Redox conditions and sulphur supply}

$\mathrm{Pr} / \mathrm{Ph}$ ratios are a widely used redox parameter (Didyk et al. 1978). The observed very low ratios, which exceed 1.0 in only two samples from Subunit 2a (Fig. 13b), suggest strictly anoxic conditions. These varied only temporarily to dysoxic conditions during deposition of Subunit 2a and the basal part of Subunit 2b. Anoxic-to-dysoxic conditions are also suggested by a cross-plot of the pristane $/ n-\mathrm{C}_{17}$ vs phytane $/ n-\mathrm{C}_{18}$ ratios (Fig. 16). Moreover, the presence of aryl isoprenoids suggests that anoxic conditions, at least temporarily, even reached into the photic zone.

Very high DBT/Phenanthrene ratios indicate high concentrations of free $\mathrm{H}_{2} \mathrm{~S}$ in the water column (Hughes et al. 1995), especially during deposition of Unit 2. However, it has to be emphasized that high ratios are caused by low phenanthrene rather than by very high DBT concentrations. In the $\mathrm{Pr} / \mathrm{Ph}$ vs DBT/Phenanthrene diagram (Hughes et al. 1995; Fig. 17), the samples plot into the field of strongly oxygen-depleted marine carbonate environments. These 


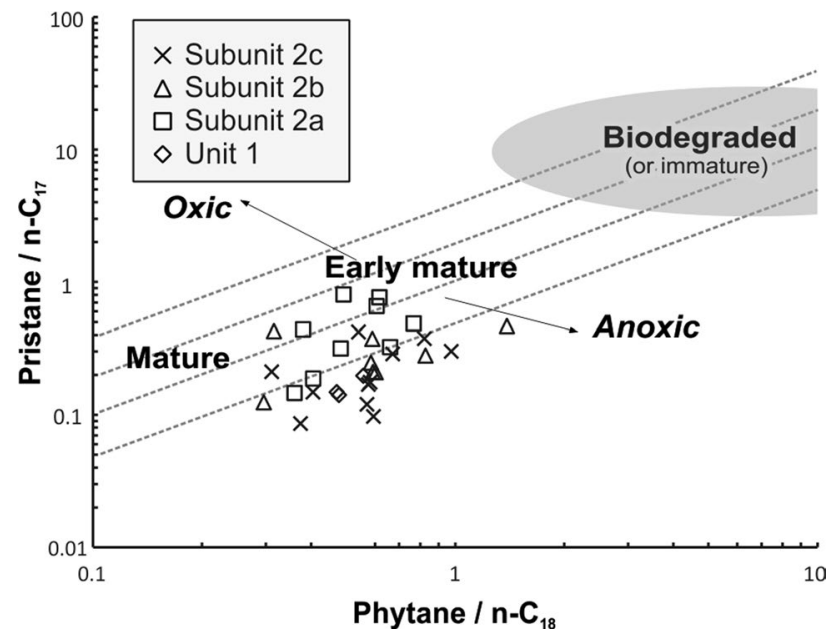

Fig. 16 Plot of pristane $/ n-\mathrm{C}_{17}$ alkane vs. phytane $/ n-\mathrm{C}_{18}$ alkane ratios

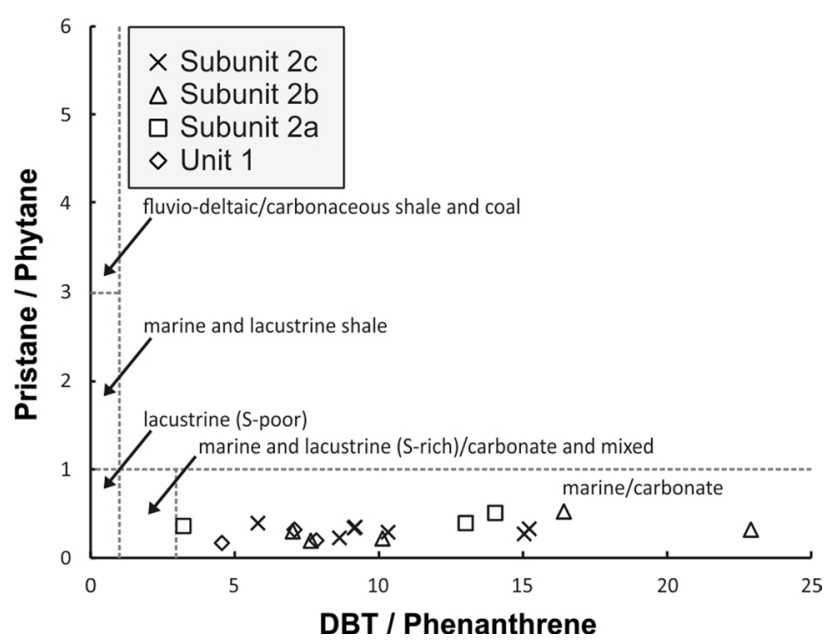

Fig. 17 Cross-plot of pristane/phytane vs. DBT/phenanthrene ratios after Hughes et al. (1995). The position of the samples agrees with a strongly oxygen-depleted marine carbonate environment

environments are often iron-limited. Therefore, sulphur is preferentially incorporated into the organic matter. This is also supported by high sulphur content in kerogen concentrates from other Lemeš locations (Blažeković Smojić et al. 2009).

Total sulphur content and resulting TOC/S ratios provide a proxy for the distinction between marine and (sulphatelimited) freshwater and between oxic and anoxic conditions (Berner and Raiswell 1983). TOC/S ratios are in average 5.46 and exceed 2.8, the value considered typical for oxic marine environments (Berner and Raiswell 1983) considerably. Only some siliceous limestones in Subunit 2c; Fig. 7) are close to 2.8. Considering the presence of radiolarians and ammonites, a brackish or freshwater environment can be excluded for the Lemeš Basin.

Weathering of the outcrop samples is a possible explanation for low sulphur contents in the studied sections. However, the presence of fresh pyrite in Unit 2 samples (Fig. 11) does not support strong weathering. Thus, it is likely that sulphate concentration in the depositional environment was not very high, but because $\mathrm{Fe}$-availability in the carbonate environment was limited, most available sulphur was incorporated in the organic matter. The dominance of very small-sized framboidal pyrites (below $4 \mu \mathrm{m}$ ) may indicate its formation within the water column (Wilkin et al. 1996; Liu et al. 2019).

Gammacerane, a proxy for salinity stratification (Sinninghe Damsté et al. 1995), is absent in all samples. However, some samples from Units $1,2 \mathrm{a}$, and $2 \mathrm{~b}$ contain pregnane (max. $19.61 \mu \mathrm{g} / \mathrm{g}$ TOC) and homopregnane (max. $18.09 \mu \mathrm{g} / \mathrm{g}$ TOC) in significant amounts, which have been considered as possible markers for hypersaline environments (Ten Haven et al. 1986; Peters et al. 2005).

In contrast to geochemical proxies, significant bioturbation in Unit 1 indicates oxygen concentrations that allowed life at the sea floor. Bioturbation is also observed in some layers in Unit 2 (e.g. Figure 4c). This suggests significant variations of redox conditions. Only organic matter-rich layers, which were deposited in dysoxic to anoxic environments, have been selected for geochemical analysis.

Despite varying oxygen conditions during deposition of Subunit 2a, TOC contents reach a maximum of $12.63 \mathrm{wt} . \%$ in this unit. This reflects high organic productivity of marine organisms in the photic zone, whereas the good preservation reflects oxygen depletion in the deeper part of the water column.

\section{Isotope composition, correlation, and paleoenvironmental effect}

$\delta^{13} \mathrm{C}_{\text {carb }}$ values $(-1.36$ to $+3.50 \%$ 。PDB $)$ are in the normal range of data from other Upper Jurassic AdCP sections ( -3.9 to $+4.3 \%$ VPDB; Fiket et al. 2008). They also fit within the gross global average of open-marine carbonates (Marshall 1992; Jenkyns et al. 2002) and follow the trend in Kimmeridgian datasets (Weissert and Erba 2004).

Vertical $\delta^{13} \mathrm{C}_{\text {carb }}$ trends of organic matter-rich and organic matter-poor limestones are similar, but $\delta^{13} \mathrm{C}_{\text {carb }}$ values from organic matter-rich limestones are up to $2 \%$ VPDB higher (Fig. 12). The enrichment of ${ }^{13} \mathrm{C}$ in these limestones may be a result of ${ }^{12} \mathrm{C}$ depletion in the surface water due to strongly increased photosynthesis (Saltzman and Thomas 2012). Thus, the difference in $\delta^{13} \mathrm{C}_{\text {carb }}$ values may reflect variations in bioproductivity. Interestingly, the difference reaches 


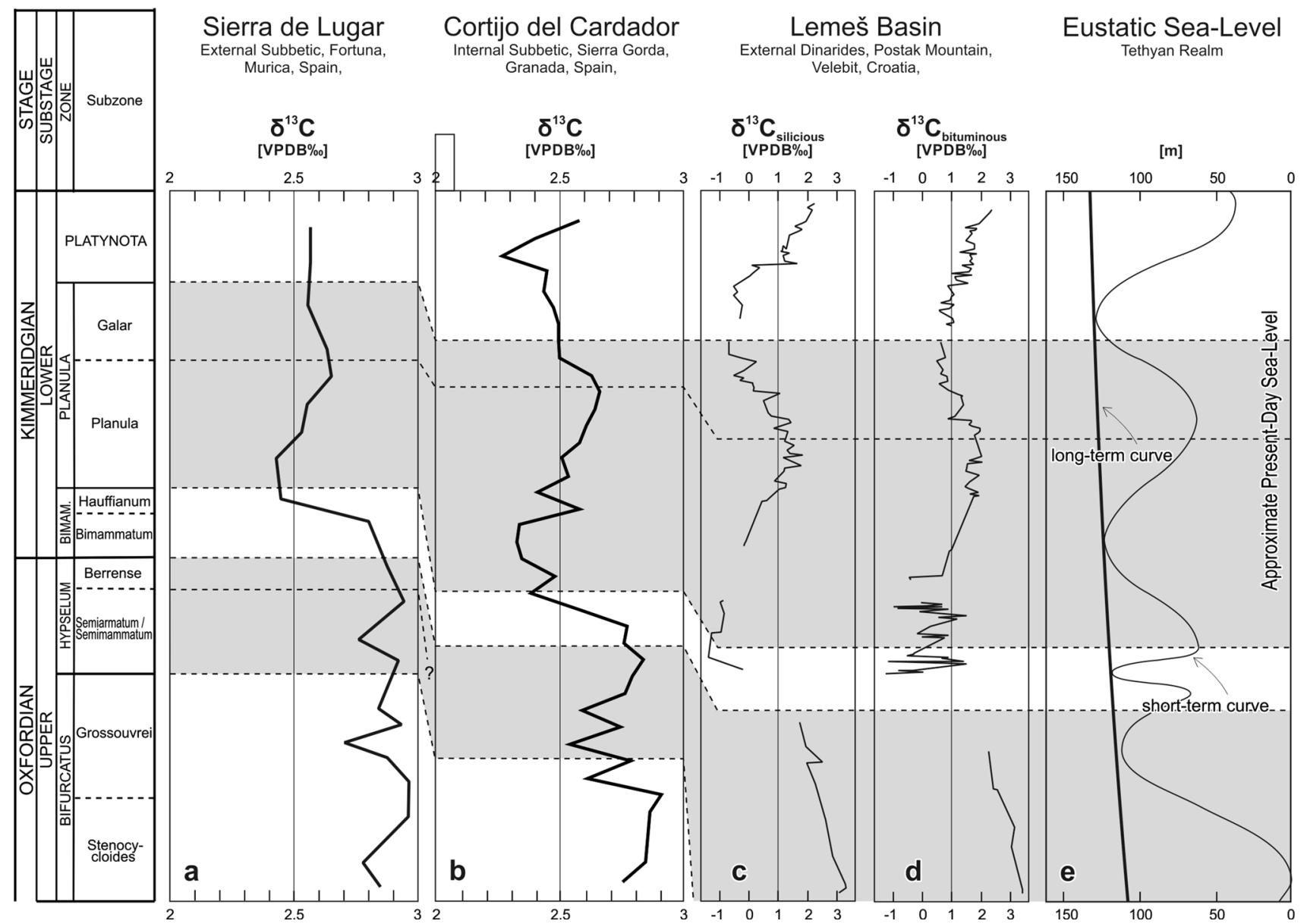

Fig. 18 Correlation of the $\delta^{13} \mathrm{C}$ isotope excursion trends of ammonite dated lower Kimmeridgian sections in Spain: a Sierra de Lugar, b Cortijo del Cardador after O'Dogherty et al. (2018), to the studied geochemical profile below the A. hypselocyclum zone, c $\delta^{13} \mathrm{C}_{\text {carb }}$ of

maxima in Unit 2a and the lower part of Unit 2c, which contain very high percentages of bituminous limestones.

In the following discussion, $\delta^{13} \mathrm{C}_{\text {carb }}$ trends are used to determine the age of the studied succession. The basal part of Unit 3 has been dated into the A. hypselocyclum ammonite zone. Therefore, the isotope trends of the underlying units (upper part of Unit 1 and Unit 2) are compared in Fig. 18 with those from the uppermost Oxfordian and lower Kimmeridgian hemipelagic limestone from the Alpine Atlantic (Missoni and Gawlick 2011) in Spain (Sierra de Lugar and Cortijo del Cardador, O'Dogherty et al. 2018). Indeed, the $\delta^{13} \mathrm{C}_{\text {carb }}$ trends in the Lemeš Basin match reasonably well with those from the western Alpine Atlantic margin in Spain (Fig. 18). However, $\delta^{13} \mathrm{C}_{\text {carb }}$ values in the Lemeš Formation show much stronger variations $(-1.36$ to $+3.50 \%$ VPDB $)$ than in the hemipelagic sections, where $\delta^{13} \mathrm{C}_{\text {carb }}$ values fall into the narrow range of $2.3-2.9 \%$ VPDB. The stronger siliceous limestones, $\mathbf{d} \delta^{13} \mathrm{C}_{\text {carb }}$ of bituminous limestones, and e the eustatic sea-level scaled to the correlated ammonite zones after Haq (2018)

negative excursions are probably an effect of limited exchange with the open oceanic carbon reservoir in the (semi-) restricted intraplatform Lemeš Basin. As pointed out by Saltzman and Thomas (2012), the restricted circulation allows larger amplitude and/or higher frequency in $\delta^{13} \mathrm{C}_{\text {carb }}$ variability than the global ocean reservoir.

The best fit between the $\delta^{13} \mathrm{C}_{\text {carb }}$ trends in the well-dated pelagic sections (Fig. 18a, b) and the Lemeš Basin (Fig. 18c, d) is observed in the lower Kimmeridgian succession. In the pelagic sections, the lower Kimmeridgian includes an interval with decreasing upward $\delta^{13} \mathrm{C}_{\text {carb }}$ values (Bimammatum ammonite zone), a minimum near the Bimammatum/Planula zone boundary, a relative maximum within the Planula ammonite zone (Planula/Galar subzones boundary), and an upward trend with decreasing $\delta^{13} \mathrm{C}_{\text {carb }}$ values. This suggests that the Unit 2a was deposited during the late Bimammatum (Hauffianum subzone) and the early Planula ammonite 
zones (Planula subzone). Unit $2 \mathrm{~b}$ represents the remaining part of the Planula ammonite zone. Unit $2 \mathrm{c}$ is tentatively attributed to the Platynota ammonite zone, although the observed trend with increasing upward $\delta^{13} \mathrm{C}_{\text {carb }}$ values is not clearly recorded in the pelagic sections. The upper part of the underlying Unit 1 shows a distinct decreasing upward trend. This may correlate with a similar trend in the Sierra de Lugar section (Berrense subzone of the Hypselum zone; Fig. 18a).

$\delta^{18} \mathrm{O}_{\text {carb }}$ values in Units 1 and 2 typically fall into the narrow range of -2.5 to $-3.5 \%$ VPDB. These values are similar to those recorded for other locations with Lemeš Formation (Fiket et al. 2008), but about 1.5\% lower than in Oxfordian and Kimmeridgian rocks in other Tethyan localities (Weissert and Erba 2004). Two outliers with highly negative values near the base of Unit 2 are assumed measurement errors. Apart from those, $\delta^{18} \mathrm{O}_{\text {carb }}$ values show a subtle decreasing upward trend. It remains speculative, if this trend reflects the warming following a late Oxfordianto-early Kimmeridgian cooling phase (Weissert and Erba 2004), or if other factors (e.g., salinity variations, paleoclimate, volcanic activity, and diagenetic processes; Hallam, 1984; Weissert and Erba 2004) contributed to the observed $\delta^{18} \mathrm{O}_{\text {carb }}$ trend.

The average $\delta^{13} \mathrm{C}$ value of organic matter $\left(\delta^{13} \mathrm{C}_{\text {org }}\right)$ is $-27.63 \%$ VPDB conforming to other Upper Jurassic AdCP data (Fiket et al. 2008). Unit 1 has uniform $\delta^{13} \mathrm{C}_{\text {org }}$ values (avg. $-26.28 \%$ VPDB), whereas Units $2 \mathrm{a}$ and $2 \mathrm{~b}$ show a trend towards more negative values. Low, but uniform $\delta^{13} \mathrm{C}_{\text {org }}$ values (avg. $-29.55 \%$ VPDB) are observed in Units $2 \mathrm{c}$. A slight trend towards more negative values is also recognized on a global scale (Jenkyns et al. 2002). In the Lemeš Basin, the onset of this trend correlates with the base of the organic matter-rich Unit 2. Largely parallel $\delta^{13} \mathrm{C}_{\text {org }}$ and $\mathrm{Pr} / \mathrm{Ph}$ trends in Unit 2 suggest that $\delta^{13} \mathrm{C}$ depletion might be related to redox conditions and carbon recycling (e.g., Küspert 1982; Hollander and Smith 2001; Jenkyns et al. 2002; Luo et al. 2014). However, changes in the organic source and specific organism assemblages may have contributed to the observed trend.

\section{Thermal maturity}

$T_{\max }$ values of siliceous (average $425^{\circ} \mathrm{C}$ ) and bituminous limestone (avg. $429^{\circ} \mathrm{C}$ ) (Fig. 8) suggest that the organic matter is immature. The light yellow fluorescence colour of liptinite macerals (Fig. 11) supports the low maturity. The average CPI value (1.22) is in agreement with an immature or early mature stage (Allan and Douglas 1977). Vitrinite reflectance of three samples $(0.39,0.47$, and $0.52 \% \mathrm{Rr})$ varies significantly, but shows that the oil window has not yet been reached.
Low maturity is also corroborated by very low $\mathrm{Ts} / \mathrm{Tm}$ ratios (avg. 0.06), the presence of thermally instable benzohopanes in some samples (Peters et al. 2005), and very low ratios of tri- and monoaromatic steroids (average 0.22) (Mackenzie et al. 1980; Riolo et al. 1986; Peters et al. 2005). MPI-1 ratios could be calculated for 17 samples (avg. $0.41)$. Vitrinite reflectance $\left(R_{\mathrm{c}}\right)$ has been calculated using the equation $\left(R_{\mathrm{c}}=0.60 \times\right.$ MPI- $1+0.40$; Radke and Welte 1981 ) and is on average $0.65 \%$. This value is slightly higher than the measured reflectance values. Vitrinite reflectance values derived from MDR values $\left(R_{\mathrm{c}}=0.4+0.3 \times\right.$ MDR $-0.094 \times \mathrm{MDR}^{2}+0.011 \times \mathrm{MDR}^{3}$; Radke, 1988) range from 0.55 to $0.63 \%$ (average $0.60 \%$ ). However, all aromatic maturity parameters may be biased by very low contents of aromatic compounds in many samples.

The average $22 S /(22 S+22 R)$ isomerization ratios of $\alpha \beta-\mathrm{C}_{32}$ hopane (0.58) are close to their equilibrium value $(\sim 0.6)$, whereas the average $20 S /(20 S+20 R)$ ratios of $\alpha \alpha \alpha-$ $\mathrm{C}_{29}$ sterane (0.49) did not yet reach equilibrium ( $\left.\sim 0.55\right)$. This suggests early oil window maturity (e.g., Seifert and Moldowan 1980, 1986).

Hence, parameters considered as most reliable ( $T_{\max }$, fluorescence colour) suggest that the organic matter is immature. However, early oil window maturity, suggested by some biomarker parameters, cannot be ruled out.

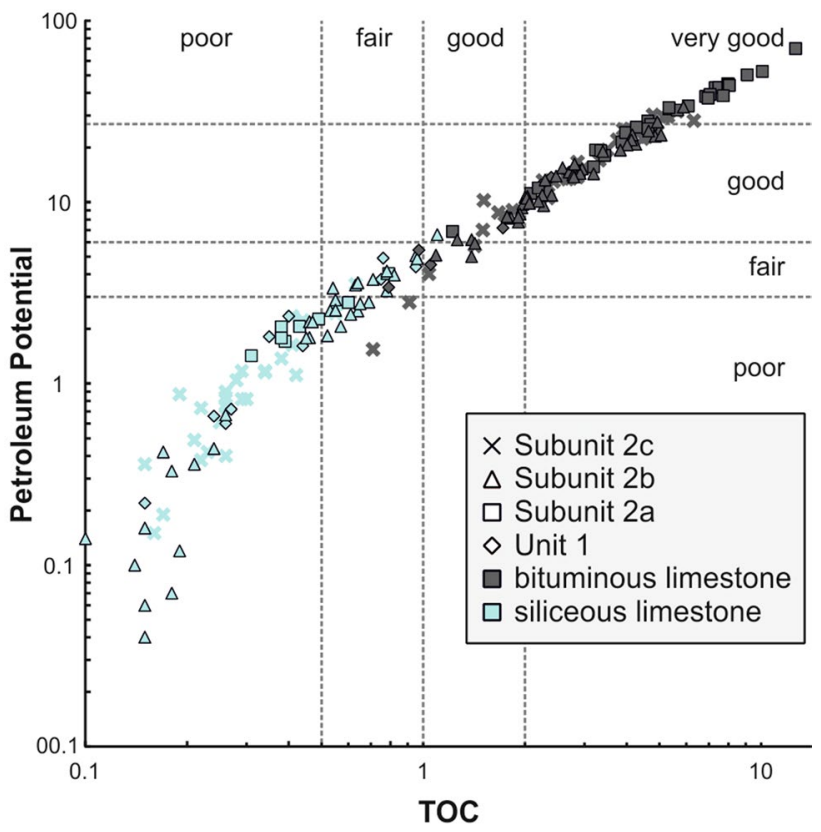

Fig. 19 Cross-plot of petroleum potential $\left(S_{1}+S_{2}\right)$ (mg HC/g rock) vs. TOC\% after Peters and Cassa (1994) 


\section{Petroleum potential}

Cross-plots of petroleum potential (PP; $S_{1}+S_{2}$ ) vs TOC are widely used for the assessment of source rock quality (Fig. 19) (Peters and Cassa 1994). Most bituminous limestones show a good-to-very good HC potential based on the PP (6-70 mg HC/g TOC) and TOC contents (1-13 wt.\%). In contrast, siliceous limestones hold poor-to-fair source potential with low PP and TOC.

The amount of hydrocarbons (in tons), which can be generated beneath $1 \mathrm{~m}^{2}$ of surface area, can be estimated using the Source Potential Index [(SPI $\left.=h \times\left(S_{1}+S_{2}\right) \times \rho / 1000\right)$; Demaison and Huizinga 1994], where $h$ is the thickness and $\rho$ the average rock density. In the present paper the density of siliceous and bituminous limestones was assumed as 2.6 and $2.4 \mathrm{t} / \mathrm{m}^{3}$, respectively. Demaison and Huizinga (1994) suggested neglecting intervals with a PP below $2 \mathrm{mg} \mathrm{HC/g}$ TOC). Only a small percentage of the samples in the organic matter-rich Unit 2 is characterized by PP values below $2 \mathrm{mg}$ $\mathrm{HC} / \mathrm{g}$ TOC. Moreover, they are evenly distributed within the studied section. Hence, these values have been also taken into account.

The SPI of Unit 2, which is $50.95 \mathrm{~m}$ thick, was calculated assuming that the percentage of bituminous limestones is similar, in both the non-exposed and exposed part of the succession (46\%). Note that the obtained SPI value $(1.32 \mathrm{t} \mathrm{HC/}$ $\mathrm{m}^{2}$ ) is a conservative estimate as it is likely that organic-rich bituminous rocks are more easily weathered than siliceous limestones.

With respect to the SPI, given the wide lateral extent of the organic-rich strata $\left(42 \mathrm{~km}^{2}\right.$; Blažeković Smojić et al. 2009) and their maximum thickness (70 m; Blažeković Smojić et al. 2009), it is evident that the Lemeš Formation

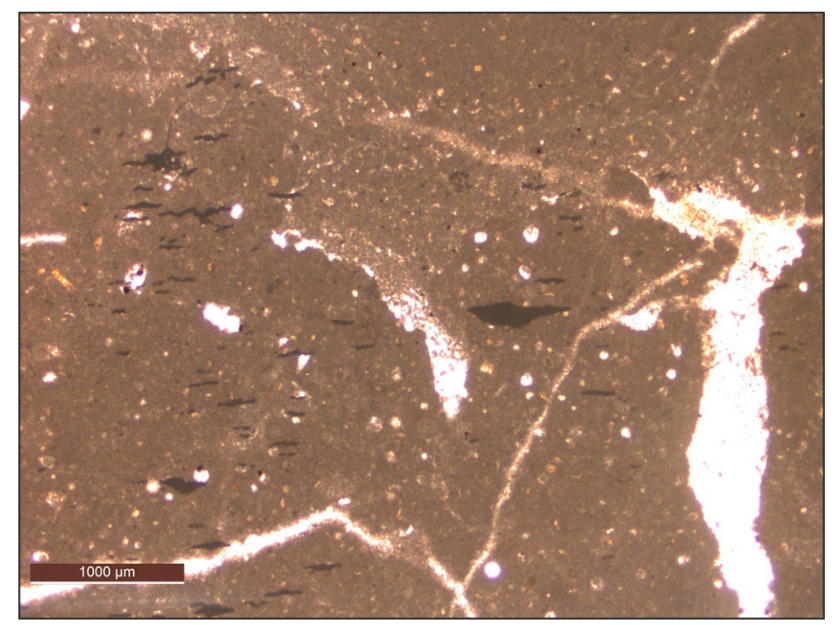

Fig. 20 Thin section microphotograph from the basal meters of Unit 3 with bit bituminous pore fills. Sample Kro 3

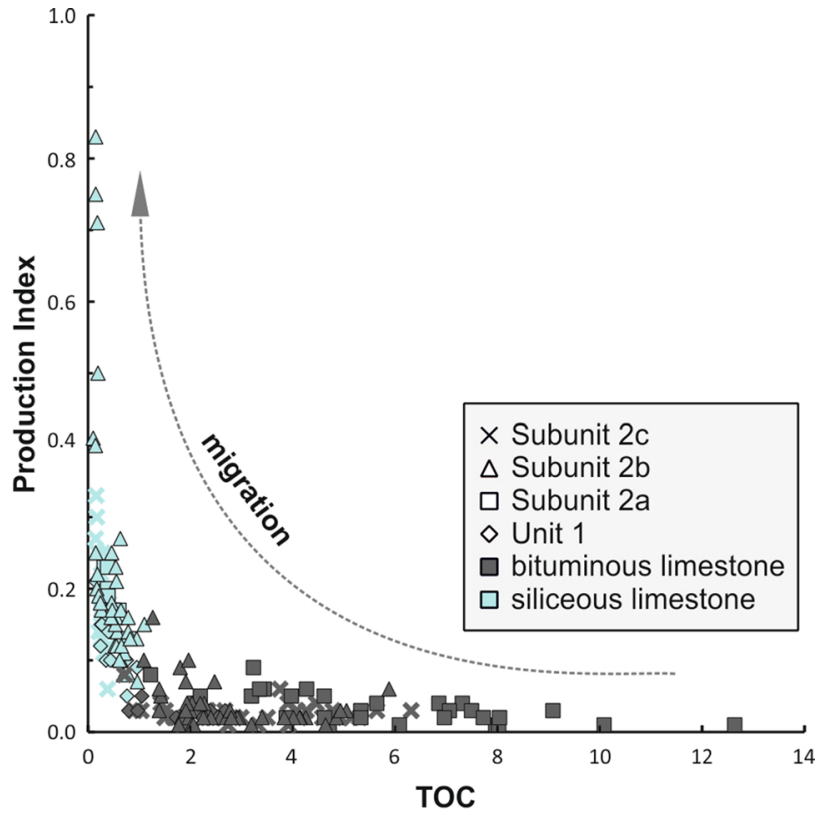

Fig. 21 Plot of Production Index $\left(S_{1} /\left(S_{1}+S_{2}\right)\right.$ vs TOC\% visualizing early hydrocarbon migration

could be a valuable source rock, provided that it reaches oil window maturity.

\section{Early hydrocarbon migration}

Although $T_{\max }$ values are significantly below the threshold value for oil generation from typical type II kerogen $\left(435^{\circ} \mathrm{C}\right.$; Tissot et al. 1987; Peters et al. 2005), bituminous matter in thin sections (Fig. 20) and polished blocks (Fig. 11) is a strong indication for generated and migrated hydrocarbons. In addition, a cross-plot of PI vs TOC (Fig. 21) shows a relative enrichment of free $S_{1}$ hydrocarbons in the siliceous limestones of Unit 2, which have low TOC contents (PI up to 0.84 ) compared to the organic-rich laminated limestones (PI up to 0.18).

Early hydrocarbon generation may be related to the presence of type II-S known for HC generation at low $T_{\max }$ values $\left(<435^{\circ} \mathrm{C}\right.$, e.g., Lewan and Ruble 2002). This interpretation is supported by high DBT/Phenathrene ratios in the studied samples. Moreover, based on very high organic sulphur contents in kerogen concentrates, Blažeković Smojić et al. (2009) suggested the presence of type II-S kerogen in other Lemeš locations.

\section{Formation of the Lemeš Basin}

The Lemeš Basin is a deep-water basin that was formed in the Late Jurassic evolution of the Adriatic Carbonate Platform, and was surrounded by shallow-water or emerged areas (Vlahović et al. 2005). Existing models explain the 
formation of the elongated southeast-to-northwest-striking basin by either (1) extensional tectonics with formation of steep escarpments (Herak 1986; Bucković et al. 2004; Bucković and Markić 2016), (2) unspecified synsedimentary tectonics (Fiket et al. 2008), or (3) transpressional strike-slip tectonics with formation of pull-apart basins (Velić et al. 2002a, b; Vlahović et al. 2005 and references therein).

However, new basins rapidly formed in extensional or strike-slip settings are bordered by steep escarpments that trigger mobilization of mass transport deposits. Such mass transport deposits are normally found near the base of the basin fill, and the component spectrum should reflect the mobilized older sedimentary sequence suddenly exposed on the steep flanks of such basins (e.g., the Jurassic sedimentary sequence of the Adriatic Carbonate Platform and its basement). Moreover, in an extensional setting, the grain size and bed thickness should reflect a fining-upward trend (Einsele 1992 and references therein). In a pull-apart setting, the trend of bed thickness and grain-size should be irregular, because depositional centers, transport routes and source areas shift (Steel and Gloppen 1980; Cemen et al. 1985). None of these sedimentological trends are observed in the Lemeš Basin, and mass transport deposits are not known. Instead, around the Oxfordian/Kimmeridgian boundary, the depositional setting shifted in a very short time span from shallow-water to deep-water carbonates. The change is gradual, not abrupt, and no evidence of fault formation, such as resediments or seismites, is observed. In the Poštak region in the central part of the Lemeš Basin, rapid subsidence started earlier (around the Oxfordian/Kimmeridgian boundary) than in the more marginal areas, such as the typearea (late Kimmeridgian).

This rapid increase in subsidence resulted in a deepening event with deposition of deep-water carbonates with chert nodules and clayey and marly intercalations. Black shales formed mainly in the depositional center of this newly formed, elongated basin. The induced subsidence during the Kimmeridgian was higher than the carbonate production potential of shallow-water settings of the AdCP (i.e., $10^{3-4} \mathrm{~B}$; see Schlager 2005 for explanation).

The water depth in the basin can only be estimated on the basis of the thickness of the basin fill. As the basin fill does not exceed $450 \mathrm{~m}$, the maximum water depth, which was during accumulation of the black shales in Unit 2, was probably not more than $250-300 \mathrm{~m}$. In contrast, the assumption of ongoing subsidence during the entire Kimmeridgian would lead to a much higher water depth estimate. The sedimentary structures indicate deposition below the wave base.

We propose the formation of the Lemeš Basin took place during Middle-to-Late Jurassic west-directed ophiolite obduction above the wider Adriatic plate (Gawlick and Missoni 2019 and references therein). During the Middle (Bajocian-to-Callovian)-to-early Late Jurassic (Oxfordian; and not in the latest Jurassic or around the Jurassic/Cretaceous boundary as proposed by Schmid et al. 2008, 2020 and references therein), a west-directed thrust belt was formed in the Inner (Internal) Dinarides below the overriding ophiolites (i.e., the wider Adriatic plate attained a lower plate position). In contrast to the Inner Dinarides, the expression of this mountain building process was relatively mild in the Outer (External) Dinarides. Here, rapidly subsiding synclines (compare Picotti and Cobianchi 2017) were formed around the Oxfordian/Kimmeridgian boundary (Fig. 22), contemporaneous with the arrival of ophiolites in the area of the Drina-Ivanjica unit and its equivalents (Porkoláb et al. 2019; Gawlick et al. 2020 and references therein). Based on subsidence analysis along a cross-section from the northeastern AdCP margin to the Adriatic basin, Picotti and Cobianchi (2017) explained the formation of such synclines as an expression of the buckling of the Adriatic lithospheric mantle as a result of far-field compression from the Tethys/ Vardar oceanic realm, coupled with formation of long wavelength $(\sim 80 \mathrm{~km})$ fold structures.

Furthermore, during Kimmeridgian-to-Tithonian times, the area of the Outer Dinarides was relatively shielded against the influence from the Tethys/Vardar Ocean, because of newly formed carbonate platforms on top of the obducted ophiolites and nappe fronts (Fig. 22b) (Schlagintweit et al. 2008; Gawlick et al. 2020). This is also expressed in the ammonite assemblage in the Lemeš Formation, which has practically no Tethyan influence (Furlani 1910).

Extensional tectonics related to the opening of the Alpine Atlantic west/northwest of the wider Adriatic plate can also be excluded in the area of Outer Dinarides for the Late Jurassic, because the oceanic break-up was much earlier, i.e., during the Toarcian (Ratschbacher et al. 2004). Consequently, during Middle-Late Jurassic times, this oceanic domain (Alpine Atlantic: Missoni and Gawlick 2011) was in a drifting stage, as documented by Bill et al. (2001).

\section{Conclusion}

The Lemeš Basin is formed during Late Jurassic time within the AdCP and is filled by the up to 450 m-thick Lemeš Formation. The Lemeš Formation is subdivided from base to top into Units 1-3. The investigation of the Lemeš Formation provides important new insights into the Late Jurassic evolution of the AdCP and deposition of organic matter-rich rocks in a restricted intraplatform basin. 


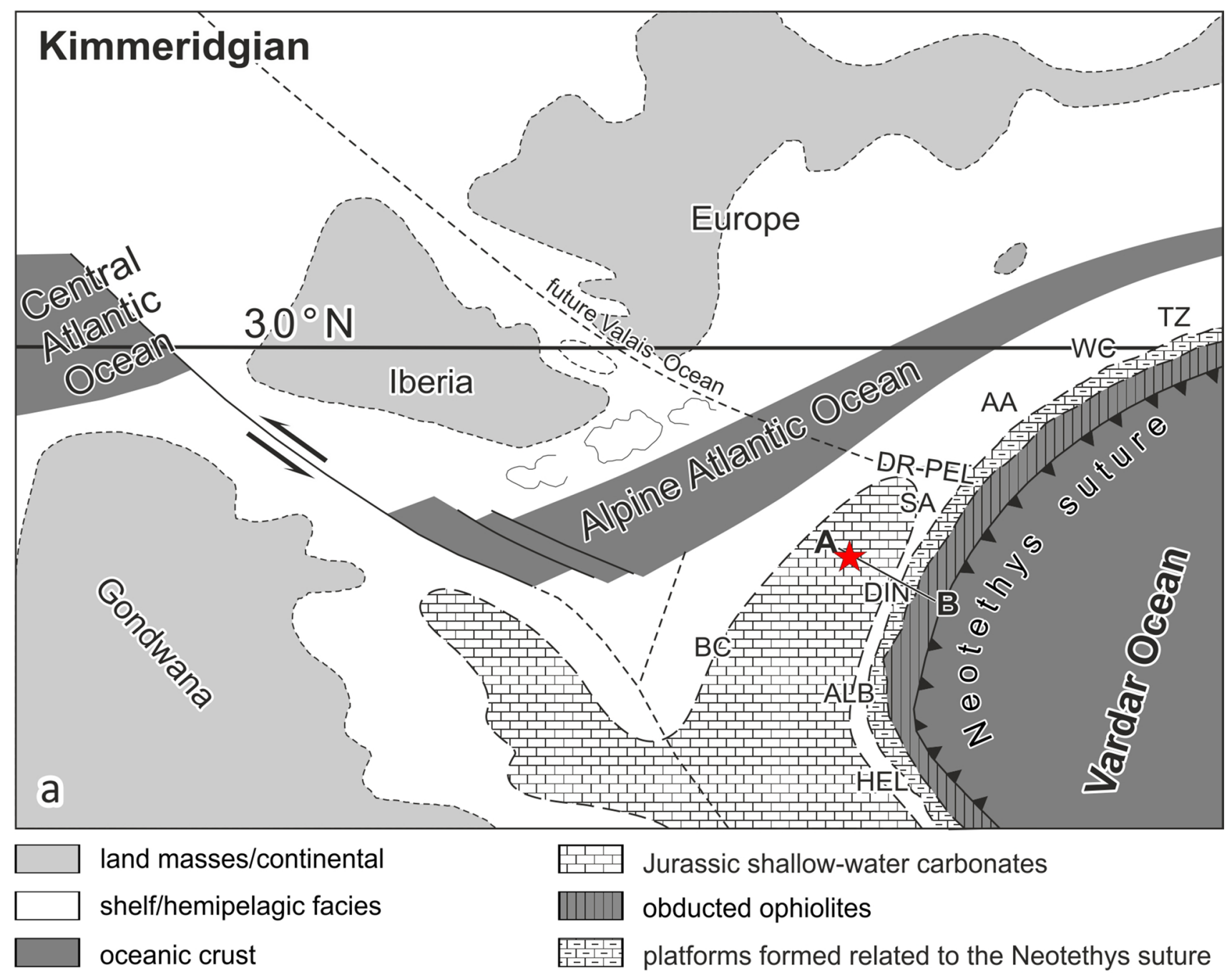

A Lemeš Basin

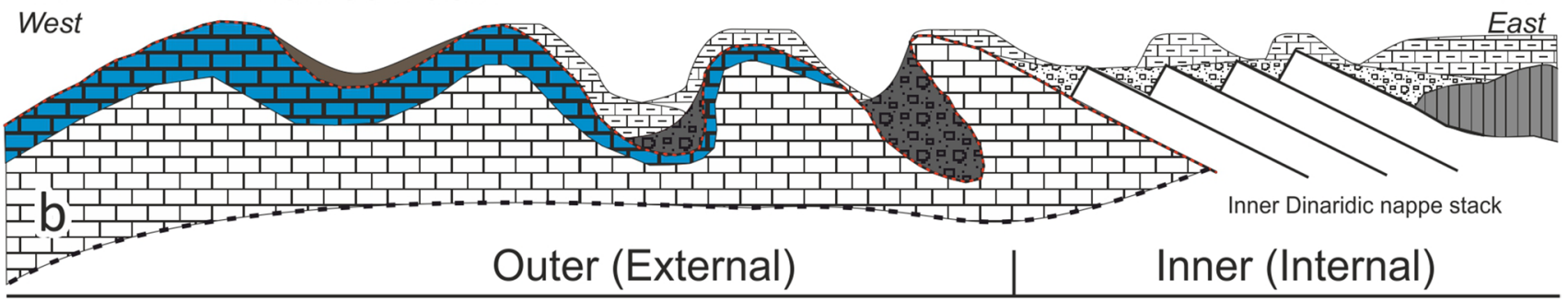

Outer (External)

DINARIDES

\begin{tabular}{|c|c|}
\hline & an Lemeš Unit \\
\hline$\underline{E}$ & Kimmeridgian platforms \\
\hline & obducte \\
\hline & lange \\
\hline
\end{tabular}

Fig. 22 a Position of the Lemeš Basin (red star) in the Kimmeridgian Western Tethyan/Vardar realm map based on Frisch (1979) and Missoni and Gawlick (2011). AA Austroalpine, $A L B$ Albanides, $B C$ Betic Cordillera, DIN Dinarides, DR-PEL Drau-Range-Pelsö, HEL Helle-

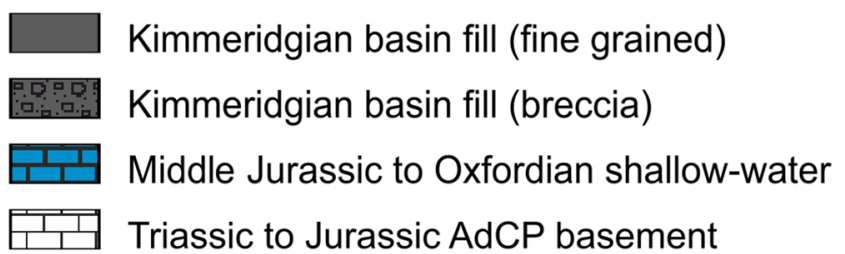

nides, $S A$ Southern Alps, TZ Tisza, $W C$ Western Carpathians; b schematic cross-section showing the buckling and folding of the AdCP as consequence of nappe stacking and west-directed ophiolite obduction (out of scale) 
- Unit 1 overlies Oxfordian shallow-water deposits. The presence of radiolarian packstones and open-marine organisms suggest a fast relative sea-level rise and a connection to open-marine environments. Input of shallowwater debris into the oxygenated basin was minor.

- Unit 2 consists of radiolarian pack- and wackegrainstones with high TOC contents (avg. 3.57 wt.\%). The general absence of bioturbation, low $\mathrm{Pr} / \mathrm{Ph}$, and very high DBT/ Phenanthrene ratios indicate strongly oxygen-depleted conditions in a (semi-)restricted basin. Water depth increased to $250-300 \mathrm{~m}$. Organic matter input was dominated by marine organisms, whereas a minor contribution of land plants, recorded by rare vitrinite particles and gymnosperm biomarkers, indicates input from nearby land areas. High bioproductivity in the oxic photic zone increased $\delta^{13} \mathrm{C}_{\text {carb }}$ values of organic matter-rich sediments.

- Unit 3 reflects a return to oxygenated conditions and is accompanied by a gradual upward increase of openmarine crinoid- and foraminifera-rich microfacies.

- The presence of Ataxioceras sp. in the basal part of the Unit 3 together with carbon isotope stratigraphy enables dating of the lower part of the Lemeš Formation. The upper part of Unit 1 accumulated during the late Oxfordian. Unit 2 represents the early Kimmeridgian E. bimammatum, I. planula and S. platynota, ammonite zones and the basal part of Unit 3 the early Kimmeridgian A. hypselocyclum ammonite zone and younger.

- The absence of major basin-bounding faults and of a sedimentary succession typical for rift or pull-apart basins suggests that the basin did not form due to extension. Based on contemporaneous ophiolite obduction in the Inner Dinarides, we propose a basin model involving subsidence due to buckling of the AdCP in the Outer Dinarides as a far-field consequence of compressional processes in the Inner Dinarides.

- Unit 2 contains good-to-very good, highly oilprone source rocks, which are thermally immature $\left(T_{\max }<430{ }^{\circ} \mathrm{C}\right)$ at the study location. When mature (e.g., in sub-thrust position), these rocks can generate approximately $1.3 \mathrm{t} \mathrm{HC} / \mathrm{m}^{2}$. High $\mathrm{HI}$ values $(502 \mathrm{mgHC} /$ gTOC) and high amounts of organic sulphur suggest the presence of kerogen type II-S. This kerogen type generates hydrocarbons at relatively low maturity. Migrated bitumen and high partially PI values are consequences of early hydrocarbon generation.

- The sedimentary Lemes Basin fill with formation of source rocks in this newly formed far-field syncline with rapid subsidence in the frame of Middle-to-Late Jurassic ophiolite obduction onto the wider Adriatic plate clearly demonstrates a potential of undetected hydrocarbon reservoirs in the nappe stack of the Dinarides. Similar restricted basins may have formed to the east and later buried below the nappes formed during the polyphase thrust processes recognized in the Dinarides (Schmid et al. 2008, 2020) or even below the ophiolites, which were transported further to the west in the frame of latest Jurassic unroofing (Gawlick et al. 2020). 
Appendix 1

\begin{tabular}{|c|c|c|c|c|c|c|c|c|c|}
\hline $\begin{array}{l}\text { Sample } \\
\text { (Cro-x) }\end{array}$ & TOC [wt.\%] & $\begin{array}{l}S_{1}[\mathrm{mg} / \mathrm{g} \\
\text { Rock] }\end{array}$ & $\begin{array}{l}S_{2}[\mathrm{mg} / \mathrm{g} \\
\text { Rock] }\end{array}$ & $T_{\max }\left[{ }^{\circ} \mathrm{C}\right]$ & $\begin{array}{l}\mathrm{HI}[\mathrm{mg} / \mathrm{g} \\
\text { TOC] }\end{array}$ & $S$ [wt.\%] & $\mathrm{Cc}_{\mathrm{eq}}$ [wt.\%] & $\begin{array}{l}\mathrm{PI}[\mathrm{mg} / \mathrm{g} \\
\text { Rock] }\end{array}$ & $\begin{array}{l}\mathrm{PP}[\mathrm{mg} / \mathrm{g} \\
\text { Rock }]\end{array}$ \\
\hline 1 & 0.15 & 0.05 & 0.17 & 434 & 114 & 0.05 & 97.3 & 0.21 & 0.22 \\
\hline 2 & 0.79 & 0.10 & 3.28 & 430 & 416 & 0.10 & 95.2 & 0.03 & 3.38 \\
\hline 3 & 0.95 & 0.39 & 4.00 & 426 & 419 & 0.15 & 96.3 & 0.09 & 4.39 \\
\hline 4 & 1.05 & 0.21 & 4.31 & 425 & 412 & 0.18 & 96.0 & 0.05 & 4.52 \\
\hline 5 & 0.26 & 0.09 & 0.51 & 427 & 195 & 0.06 & 96.9 & 0.15 & 0.60 \\
\hline 6 & 0.24 & 0.08 & 0.58 & 427 & 239 & 0.05 & 97.3 & 0.12 & 0.66 \\
\hline 7 & 1.72 & 0.16 & 7.04 & 425 & 409 & 0.26 & 94.3 & 0.02 & 7.20 \\
\hline 8 & 2.23 & 0.28 & 12.16 & 430 & 545 & 0.34 & 94.8 & 0.02 & 12.44 \\
\hline 9 & 0.27 & 0.11 & 0.61 & 428 & 230 & 0.06 & 97.9 & 0.15 & 0.72 \\
\hline 10 & 2.39 & 0.37 & 13.31 & 429 & 557 & 0.44 & 95.6 & 0.03 & 13.68 \\
\hline 11 & 0.97 & 0.19 & 5.25 & 425 & 540 & 0.21 & 98.1 & 0.03 & 5.44 \\
\hline 12 & 0.40 & 0.34 & 2.01 & 427 & 503 & 0.09 & 98.2 & 0.14 & 2.35 \\
\hline 13 & 0.35 & 0.19 & 1.62 & 425 & 458 & 0.08 & 98.2 & 0.10 & 1.81 \\
\hline 14 & 0.76 & 0.24 & 4.67 & 427 & 616 & 0.16 & 97.5 & 0.05 & 4.91 \\
\hline 15 & 2.68 & 0.49 & 13.96 & 429 & 520 & 0.36 & 91.9 & 0.03 & 14.45 \\
\hline 16 & 0.75 & 0.38 & 3.37 & 427 & 451 & 0.13 & 96.8 & 0.10 & 3.75 \\
\hline 17 & 0.44 & 0.17 & 1.44 & 428 & 326 & 0.06 & 97.5 & 0.10 & 1.61 \\
\hline 18 & 2.08 & 0.41 & 10.74 & 428 & 516 & 0.36 & 84.5 & 0.04 & 11.15 \\
\hline 19 & 0.79 & 0.52 & 3.51 & 425 & 446 & 0.12 & 96.1 & 0.13 & 4.03 \\
\hline 20 & 2.19 & 0.55 & 11.41 & 431 & 520 & 0.34 & 23.5 & 0.05 & 11.96 \\
\hline 21 & 0.43 & 0.35 & 1.71 & 424 & 394 & 0.06 & 92.8 & 0.17 & 2.06 \\
\hline 22 & 3.87 & 0.47 & 20.94 & 431 & 541 & 0.75 & 91.7 & 0.02 & 21.41 \\
\hline 23 & 1.22 & 0.54 & 6.34 & 430 & 519 & 0.21 & 96.3 & 0.08 & 6.88 \\
\hline 24 & 9.08 & 1.76 & 48.54 & 431 & 534 & 1.49 & 76.3 & 0.03 & 50.30 \\
\hline 25 & 3.97 & 1.18 & 22.96 & 428 & 579 & 0.61 & 66.9 & 0.05 & 24.14 \\
\hline 26 & 7.31 & 1.73 & 41.02 & 430 & 561 & 1.23 & 63.8 & 0.04 & 42.75 \\
\hline 27 & 3.19 & 0.81 & 14.86 & 430 & 466 & 0.52 & 0.75 & 0.05 & 15.67 \\
\hline 28 & 0.38 & 0.41 & 1.64 & 423 & 429 & 0.05 & 96.7 & 0.20 & 2.05 \\
\hline 29 & 12.63 & 0.57 & 69.62 & 430 & 551 & 2.01 & 74.6 & 0.01 & 70.19 \\
\hline 30 & 3.44 & 1.03 & 17.04 & 432 & 496 & 0.57 & 3.58 & 0.06 & 18.07 \\
\hline 31 & 10.08 & 0.69 & 51.9 & 430 & 515 & 1.80 & 75.9 & 0.01 & 52.59 \\
\hline 32 & 5.33 & 0.90 & 31.74 & 429 & 596 & 0.94 & 88.4 & 0.03 & 32.64 \\
\hline 33 & 4.61 & 1.37 & 26.59 & 434 & 577 & 0.86 & 85.8 & 0.05 & 27.96 \\
\hline 34 & 7.49 & 1.23 & 41.6 & 432 & 556 & 1.47 & 84.8 & 0.03 & 42.83 \\
\hline 35 & 6.08 & 0.33 & 33.57 & 429 & 552 & 1.00 & 80.3 & 0.01 & 33.90 \\
\hline 36 & 0.49 & 0.40 & 1.87 & 424 & 377 & 0.08 & 94.1 & 0.17 & 2.27 \\
\hline 37 & 7.96 & 0.45 & 44.52 & 433 & 559 & 1.31 & 80.5 & 0.01 & 44.97 \\
\hline 38 & 0.31 & 0.33 & 1.09 & 421 & 346 & 0.06 & 96.6 & 0.23 & 1.42 \\
\hline 39 & 4.27 & 1.44 & 24.47 & 432 & 574 & 0.82 & 90.7 & 0.06 & 25.91 \\
\hline 40 & 4.71 & 0.35 & 26.5 & 429 & 563 & 0.84 & 82.8 & 0.01 & 26.85 \\
\hline 41 & 5.64 & 1.25 & 30.95 & 434 & 549 & 0.91 & 34.9 & 0.04 & 32.20 \\
\hline 42 & 5.33 & 0.73 & 32.49 & 433 & 609 & 0.99 & 88.5 & 0.02 & 33.22 \\
\hline 43 & 0.39 & 0.32 & 1.38 & 423 & 353 & 0.06 & 94.3 & 0.19 & 1.70 \\
\hline 44 & 8.02 & 0.51 & 44.07 & 434 & 550 & 1.41 & 83.3 & 0.01 & 44.58 \\
\hline 45 & 6.85 & 1.68 & 36.53 & 431 & 533 & 1.27 & 75.1 & 0.04 & 38.21 \\
\hline 46 & 7.06 & 1.34 & 37.91 & 432 & 537 & 1.18 & 84.7 & 0.03 & 39.25 \\
\hline 47 & 3.23 & 1.74 & 17.65 & 431 & 546 & 0.48 & 90.7 & 0.09 & 19.39 \\
\hline
\end{tabular}




\begin{tabular}{|c|c|c|c|c|c|c|c|c|c|}
\hline $\begin{array}{l}\text { Sample } \\
\text { (Cro-x) }\end{array}$ & TOC [wt.\%] & $\begin{array}{l}S_{1}[\mathrm{mg} / \mathrm{g} \\
\text { Rock] }\end{array}$ & $\begin{array}{l}S_{2}[\mathrm{mg} / \mathrm{g} \\
\text { Rock }]\end{array}$ & $T_{\max }\left[{ }^{\circ} \mathrm{C}\right]$ & $\begin{array}{l}\mathrm{HI}[\mathrm{mg} / \mathrm{g} \\
\text { TOC] }\end{array}$ & $S$ [wt.\%] & $\mathrm{Cc}_{\mathrm{eq}}[\mathrm{wt} . \%]$ & $\begin{array}{l}\text { PI [mg/g } \\
\text { Rock] }\end{array}$ & $\begin{array}{l}\text { PP }[\mathrm{mg} / \mathrm{g} \\
\text { Rock }]\end{array}$ \\
\hline$\overline{48}$ & 8.04 & 0.75 & 43.3 & 430 & 538 & 1.27 & 82.8 & 0.02 & 44.05 \\
\hline 49 & 3.35 & 1.21 & 17.99 & 430 & 537 & 0.53 & 89.0 & 0.06 & 19.20 \\
\hline 50 & 6.96 & 0.84 & 36.62 & 430 & 526 & 1.13 & 84.9 & 0.02 & 37.46 \\
\hline 51 & 0.60 & 0.48 & 2.31 & 426 & 383 & 0.09 & 92.1 & 0.17 & 2.79 \\
\hline 52 & 7.72 & 0.64 & 37.95 & 431 & 492 & 1.19 & 84.0 & 0.02 & 38.59 \\
\hline 53 & 0.38 & 0.41 & 1.37 & 421 & 361 & 0.05 & 94.5 & 0.23 & 1.78 \\
\hline 54 & 4.62 & 0.39 & 25.00 & 426 & 542 & 0.70 & 89.3 & 0.02 & 25.39 \\
\hline 55 & 2.03 & 0.41 & 10.32 & 430 & 507 & 0.41 & 39.1 & 0.04 & 10.73 \\
\hline 56 & 2.29 & 0.22 & 13.01 & 429 & 569 & 0.36 & 93.1 & 0.02 & 13.23 \\
\hline 57 & 1.80 & 0.76 & 7.42 & 430 & 412 & 0.34 & 32.3 & 0.09 & 8.18 \\
\hline 58 & 1.96 & 0.94 & 8.33 & 429 & 424 & 0.35 & 86.1 & 0.10 & 9.27 \\
\hline 59 & 3.19 & 0.16 & 14.13 & 428 & 443 & 0.47 & 87.3 & 0.01 & 14.29 \\
\hline 60 & 0.55 & 0.45 & 2.43 & 423 & 444 & 0.09 & 76.8 & 0.16 & 2.88 \\
\hline 61 & 0.69 & 0.23 & 2.58 & 427 & 375 & 0.09 & 95.2 & 0.08 & 2.81 \\
\hline 62 & 0.15 & 0.04 & 0.12 & 432 & 81 & 0.04 & 95.8 & 0.25 & 0.16 \\
\hline 63 & 4.25 & 0.32 & 20.48 & 430 & 481 & 0.74 & 86.6 & 0.02 & 20.80 \\
\hline 64 & 0.57 & 0.29 & 1.77 & 420 & 310 & 0.09 & 93.1 & 0.14 & 2.06 \\
\hline 65 & 4.85 & 0.55 & 22.53 & 430 & 464 & 0.79 & 88.2 & 0.02 & 23.08 \\
\hline 66 & 2.47 & 0.96 & 12.94 & 430 & 525 & 0.45 & 55.1 & 0.07 & 13.90 \\
\hline 67 & 2.27 & 0.34 & 9.23 & 428 & 406 & 0.32 & 88.0 & 0.04 & 9.57 \\
\hline 68 & 0.53 & 0.39 & 2.13 & 425 & 403 & 0.08 & 93.1 & 0.15 & 2.52 \\
\hline 69 & 0.17 & 0.09 & 0.33 & 429 & 195 & 0.04 & 96.2 & 0.20 & 0.42 \\
\hline 70 & 1.82 & 0.18 & 7.99 & 428 & 439 & 0.25 & 70.0 & 0.02 & 8.17 \\
\hline 71 & 1.09 & 0.52 & 4.57 & 422 & 421 & 0.15 & 57.8 & 0.10 & 5.09 \\
\hline 72 & 0.18 & 0.05 & 0.02 & 432 & 11 & 0.04 & 96.3 & 0.71 & 0.07 \\
\hline 73 & 0.19 & 0.06 & 0.06 & 432 & 32 & 0.04 & 97.0 & 0.50 & 0.12 \\
\hline 74 & 2.90 & 0.28 & 14.64 & 429 & 505 & 0.62 & 86.8 & 0.02 & 14.92 \\
\hline 75 & 5.05 & 0.74 & 22.62 & 431 & 448 & 0.84 & 87.4 & 0.03 & 23.36 \\
\hline 76 & 0.55 & 0.53 & 1.99 & 425 & 362 & 0.08 & 93.8 & 0.21 & 2.52 \\
\hline 77 & 4.15 & 0.54 & 22.89 & 426 & 551 & 0.69 & 85.0 & 0.02 & 23.43 \\
\hline 78 & 0.21 & 0.07 & 0.29 & 425 & 140 & 0.03 & 96.9 & 0.19 & 0.36 \\
\hline 79 & 2.95 & 0.26 & 14.95 & 424 & 508 & 0.39 & 8735 & 0.02 & 15.21 \\
\hline 80 & 0.46 & 0.44 & 1.35 & 425 & 292 & 0.09 & 96.2 & 0.25 & 1.79 \\
\hline 81 & 4.93 & 0.72 & 26.95 & 425 & 546 & 0.67 & 81.7 & 0.03 & 27.67 \\
\hline 82 & 5.88 & 1.89 & 31.54 & 426 & 536 & 0.94 & 85.6 & 0.06 & 33.43 \\
\hline 83 & 4.64 & 0.35 & 24.29 & 432 & 524 & 0.59 & 82.0 & 0.01 & 24.64 \\
\hline 84 & 0.52 & 0.22 & 1.61 & 427 & 312 & 0.09 & 95.2 & 0.12 & 1.83 \\
\hline 85 & 1.39 & 0.20 & 6.00 & 425 & 432 & 0.19 & 93.6 & 0.03 & 6.20 \\
\hline 86 & 0.15 & 0.05 & 0.01 & 425 & 7 & 0.03 & 98.6 & 0.83 & 0.06 \\
\hline 87 & 0.46 & 0.39 & 1.80 & 428 & 387 & 0.1 & 97.5 & 0.18 & 2.19 \\
\hline 88 & 2.58 & 0.26 & 15.18 & 426 & 588 & 0.34 & 94.3 & 0.02 & 15.44 \\
\hline 89 & 0.18 & 0.07 & 0.26 & 424 & 139 & 0.04 & 97.9 & 0.22 & 0.33 \\
\hline 90 & 0.10 & 0.06 & 0.08 & 428 & 79 & 0.03 & 98.0 & 0.41 & 0.14 \\
\hline 91 & 0.45 & 0.29 & 1.49 & 425 & 329 & 0.08 & 97.3 & 0.16 & 1.78 \\
\hline 92 & 0.15 & 0.03 & 0.01 & 430 & 7 & 0.03 & 97.6 & 0.75 & 0.04 \\
\hline 93 & 4.13 & 0.44 & 21.56 & 425 & 522 & 0.61 & 88.5 & 0.02 & 22.00 \\
\hline 94 & 0.55 & 0.32 & 2.21 & 424 & 401 & 0.11 & 98.3 & 0.12 & 2.53 \\
\hline 95 & 2.40 & 0.21 & 10.69 & 430 & 445 & 0.36 & 95.0 & 0.02 & 10.90 \\
\hline 96 & 2.91 & 0.27 & 14.07 & 429 & 484 & 0.42 & 93.5 & 0.02 & 14.34 \\
\hline 97 & 0.26 & 0.11 & 0.56 & 430 & 216 & 0.04 & 98.9 & 0.17 & 0.67 \\
\hline
\end{tabular}




\begin{tabular}{|c|c|c|c|c|c|c|c|c|c|}
\hline $\begin{array}{l}\text { Sample } \\
\text { (Cro-x) }\end{array}$ & TOC [wt.\%] & $\begin{array}{l}S_{1}[\mathrm{mg} / \mathrm{g} \\
\text { Rock] }\end{array}$ & $\begin{array}{l}S_{2}[\mathrm{mg} / \mathrm{g} \\
\text { Rock] }\end{array}$ & $T_{\max }\left[{ }^{\circ} \mathrm{C}\right]$ & $\begin{array}{l}\mathrm{HI}[\mathrm{mg} / \mathrm{g} \\
\text { TOC] }\end{array}$ & $S$ [wt.\%] & $\mathrm{Cc}_{\mathrm{eq}}$ [wt.\%] & $\begin{array}{l}\text { PI [mg/g } \\
\text { Rock] }\end{array}$ & $\begin{array}{l}\mathrm{PP}[\mathrm{mg} / \mathrm{g} \\
\text { Rock] }\end{array}$ \\
\hline$\overline{98}$ & 1.42 & 0.31 & 5.6 & 430 & 395 & 0.23 & 85.3 & 0.05 & 5.91 \\
\hline 99 & 2.70 & 0.23 & 14.41 & 431 & 533 & 0.49 & 92.4 & 0.02 & 14.64 \\
\hline 100 & 0.78 & 0.57 & 3.46 & 418 & 441 & 0.15 & 93.4 & 0.14 & 4.03 \\
\hline 101 & 2.00 & 0.33 & 10.29 & 425 & 515 & 0.41 & 92.3 & 0.03 & 10.62 \\
\hline 102 & 1.97 & 0.24 & 9.48 & 430 & 482 & 0.34 & 93.9 & 0.02 & 9.72 \\
\hline 103 & 0.78 & 0.25 & 2.99 & 418 & 384 & 0.16 & 93.9 & 0.08 & 3.24 \\
\hline 104 & 2.77 & 0.43 & 13.68 & 430 & 494 & 0.43 & 92.2 & 0.03 & 14.11 \\
\hline 105 & 2.02 & 0.13 & 10.37 & 431 & 514 & 0.34 & 90.7 & 0.01 & 10.50 \\
\hline 106 & 0.64 & 0.25 & 2.26 & 427 & 353 & 0.14 & 94.6 & 0.10 & 2.51 \\
\hline 107 & 2.25 & 0.21 & 10.73 & 429 & 476 & 0.34 & 88.6 & 0.02 & 10.94 \\
\hline 108 & 0.47 & 0.38 & 1.80 & 419 & 384 & 0.12 & 96.1 & 0.17 & 2.18 \\
\hline 109 & 3.40 & 0.33 & 18.65 & 432 & 548 & 0.83 & 94.1 & 0.02 & 18.98 \\
\hline 110 & 0.14 & 0.04 & 0.06 & 428 & 42 & 0.06 & 97.4 & 0.40 & 0.10 \\
\hline 111 & 1.26 & 1.00 & 5.19 & 424 & 411 & 0.24 & 94.9 & 0.16 & 6.19 \\
\hline 112 & 1.93 & 0.39 & 8.19 & 431 & 423 & 0.31 & 92.9 & 0.04 & 8.58 \\
\hline 113 & 0.95 & 0.67 & 4.39 & 423 & 462 & 0.19 & 96.3 & 0.13 & 5.06 \\
\hline 114 & 2.19 & 0.36 & 9.74 & 429 & 445 & 0.36 & 91.2 & 0.04 & 10.10 \\
\hline 115 & 0.63 & 0.95 & 2.53 & 421 & 401 & 0.12 & 93.8 & 0.27 & 3.48 \\
\hline 116 & 1.91 & 0.55 & 7.2 & 429 & 378 & 0.3 & 48.1 & 0.07 & 7.75 \\
\hline 117 & 0.71 & 0.41 & 3.33 & 425 & 468 & 0.11 & 96.2 & 0.11 & 3.74 \\
\hline 118 & 1.10 & 0.96 & 5.65 & 427 & 512 & 0.18 & 94.9 & 0.15 & 6.61 \\
\hline 178 & 0.29 & 0.11 & 0.71 & 427 & 245 & 0.18 & 93.8 & 0.13 & 0.82 \\
\hline 179 & 4.91 & 0.40 & 24.40 & 428 & 497 & 0.67 & 84.8 & 0.02 & 24.80 \\
\hline 180 & 2.86 & 0.31 & 13.44 & 423 & 469 & 0.39 & 76.3 & 0.02 & 13.75 \\
\hline 181 & 0.42 & 0.13 & 0.98 & 427 & 230 & 0.11 & 94.0 & 0.11 & 1.11 \\
\hline 182 & 0.26 & 0.15 & 0.59 & 421 & 226 & 0.07 & 97.0 & 0.20 & 0.74 \\
\hline 183 & 4.81 & 0.52 & 24.76 & 432 & 515 & 0.65 & 81.9 & 0.02 & 25.28 \\
\hline 184 & 0.23 & 0.08 & 0.34 & 427 & 147 & 0.09 & 98.0 & 0.19 & 0.42 \\
\hline 185 & 1.42 & 0.23 & 5.50 & 430 & 388 & 0.21 & 86.8 & 0.04 & 5.73 \\
\hline 186 & 0.30 & 0.09 & 0.73 & 427 & 243 & 0.10 & 96.3 & 0.11 & 0.82 \\
\hline 187 & 4.58 & 0.47 & 22.42 & 432 & 489 & 0.64 & 83.0 & 0.02 & 22.89 \\
\hline 188 & 0.25 & 0.08 & 0.53 & 428 & 213 & 0.09 & 97.2 & 0.13 & 0.61 \\
\hline 189 & 2.34 & 0.24 & 10.3 & 421 & 441 & 0.34 & 90.7 & 0.02 & 10.54 \\
\hline 190 & 0.38 & 0.08 & 1.29 & 425 & 337 & 0.12 & 96.1 & 0.06 & 1.37 \\
\hline 191 & 1.04 & 0.14 & 3.88 & 427 & 372 & 0.19 & 89.0 & 0.03 & 4.02 \\
\hline 192 & 0.22 & 0.08 & 0.30 & 425 & 136 & 0.05 & 96.3 & 0.20 & 0.38 \\
\hline 193 & 6.31 & 0.76 & 27.39 & 427 & 434 & 0.85 & 78.8 & 0.03 & 28.15 \\
\hline 194 & 0.34 & 0.13 & 1.04 & 427 & 302 & 0.10 & 98.2 & 0.11 & 1.17 \\
\hline 195 & 1.50 & 0.12 & 6.88 & 430 & 459 & 0.24 & 93.6 & 0.02 & 7.00 \\
\hline 196 & 0.26 & 0.09 & 0.31 & 432 & 122 & 0.11 & 96.5 & 0.22 & 0.40 \\
\hline 197 & 0.15 & 0.10 & 0.26 & 427 & 176 & 0.06 & 98.4 & 0.27 & 0.36 \\
\hline 198 & 2.43 & 0.21 & 12.8 & 432 & 527 & 0.32 & 93.4 & 0.02 & 13.01 \\
\hline 199 & 0.16 & 0.05 & 0.10 & 430 & 62 & 0.17 & 96.3 & 0.33 & 0.15 \\
\hline 200 & 2.26 & 0.32 & 12.83 & 430 & 568 & 0.31 & 94.7 & 0.02 & 13.15 \\
\hline 201 & 0.19 & 0.22 & 0.65 & 425 & 334 & 0.08 & 100.3 & 0.25 & 0.87 \\
\hline 202 & 0.17 & 0.06 & 0.13 & 429 & 77 & 0.08 & 97.4 & 0.30 & 0.19 \\
\hline
\end{tabular}

$T_{\max }$ Rock Eval, $S_{2}$ temperature of maximum hydrocarbon generation, $H I$ Hydrogen Index, $S$ sulphur content, $C c_{e q}$ calcite equivalent, $P I$ Production Index, $P P$ petroleum potential 


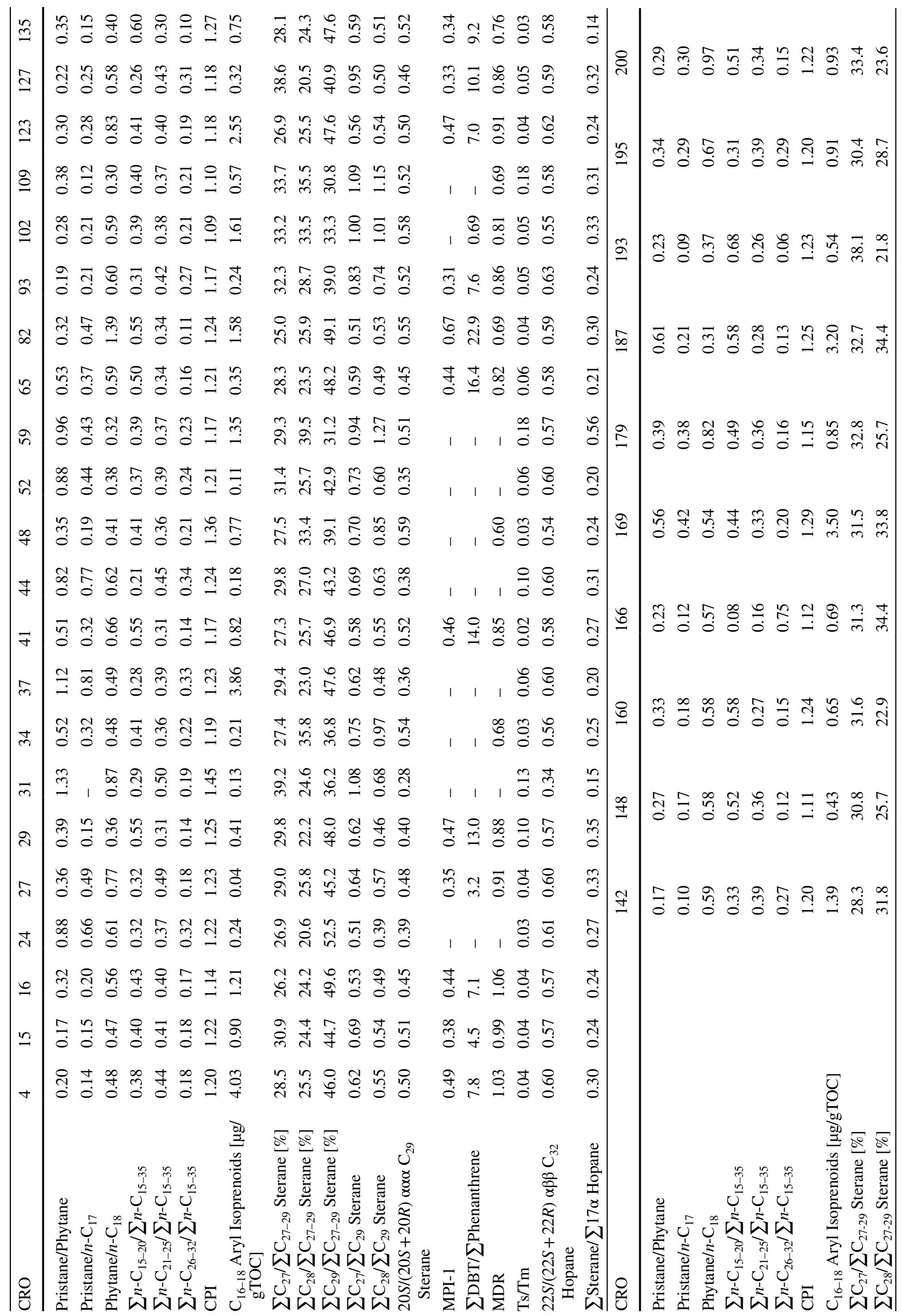




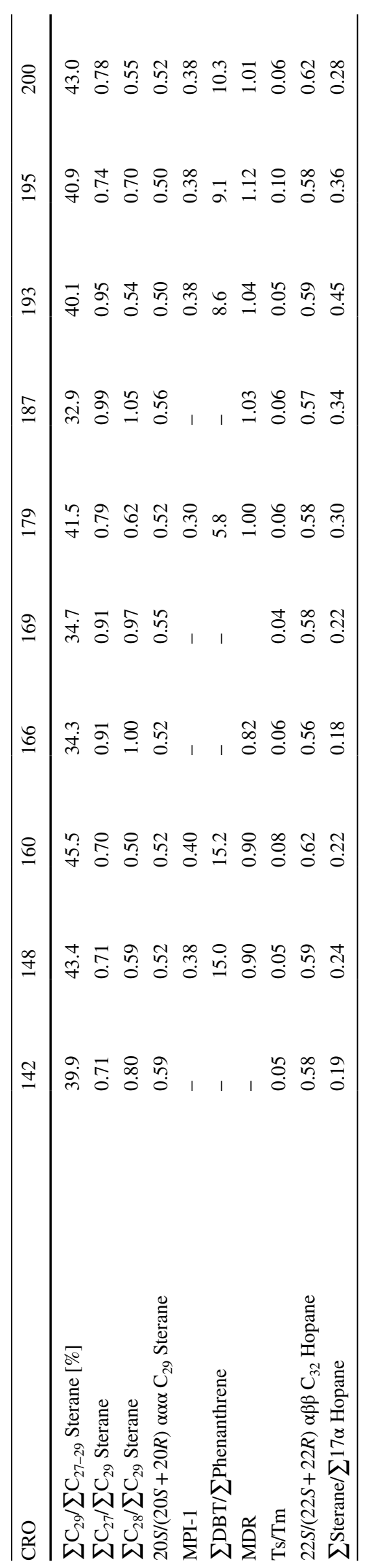


Acknowledgements We specially thank Stephen Ajuba, Doris Gross, Reinhard Gratzer, and Achim Bechtel (Montanuniversitaet Leoben) for their support, guidance, and consultation during analysis and laboratory work. Additionally, we thank Laszlo Bujtor (Pécs) for the preparation, photographs, and identification the ammonite Ataxioceras sp. Careful reviews of Herbert Volk (Hampton Hill) and Anonymous as well as linguistic improvements by Joel Bensing are grateful acknowledged.

Funding Open access funding provided by Montanuniversität Leoben.

Open Access This article is licensed under a Creative Commons Attribution 4.0 International License, which permits use, sharing, adaptation, distribution and reproduction in any medium or format, as long as you give appropriate credit to the original author(s) and the source, provide a link to the Creative Commons licence, and indicate if changes were made. The images or other third party material in this article are included in the article's Creative Commons licence, unless indicated otherwise in a credit line to the material. If material is not included in the article's Creative Commons licence and your intended use is not permitted by statutory regulation or exceeds the permitted use, you will need to obtain permission directly from the copyright holder. To view a copy of this licence, visit http://creativecommons.org/licenses/by/4.0/.

\section{References}

Affouri H, Montacer M, Disnar J-R (2013) Organic geochemistry of the Cenomanian-Turonian Bahloul formation Petroleum Source Rock, Central and Northern Tunisia. Resour Geol 63:262-287. https://doi.org/10.1111/rge. 12008

Aghayeva V, Sachsenhofer RF, van Baak CGC, Bechtel A, Hoyle TM, Selby D, Shiyanova N, Vincent SJ (2021) New geochemical insights into Cenozoic source rocks in Azerbaijan: implications for petroleum systems in the South Caspian Region. J Petrol Geol 44:349-384. https://doi.org/10.1111/jpg.12797

Allan J, Douglas AG (1977) Variations in the content and distribution of $n$-alkanes in a series of carboniferous vitrinites and sporinites of bituminous rank. Geochim Cosmochim Acta 41:1223-1230. https://doi.org/10.1016/0016-7037(77)90068-0

Atrops F (1982) La sous-Famille des Ataxioceratinae (Ammonitina) dans le Kimmeridgien inferieur de Sud-Est de la France: Systematique, evolution, chronostratigraphie des genres Orthosphinctes et Ataxioceras. Documents Des Laboratoires De Geologie Lyon 83:1-463

Barić G, Maričić M, Radić J (1988) Geochemical characterization of organic facies in the Dugi Otok basin, the Adriatic sea (Yugoslavia). Org Geochem 13:343-349. https://doi.org/10.1016/01466380(88)90054-X

Berner RA, Raiswell R (1983) Burial of organic carbon and pyrite sulfur in sediments over phanerozoic time: a new theory. Geochim Cosmochim Acta 47:855-862. https://doi.org/10.1016/ 0016-7037(83)90151-5

Bill M, O’Dogherty L, Guex J, Baumgartner PO, Masson H (2001) Radiolarite ages in Alpine-Mediterranean ophiolites: constraints on the oceanic spreading and the Tethys-Atlantic connection. Geol Soc Am Bull 113:129-143. https://doi.org/10.1130/00167606(2001)113\%3c0129:RAIAMO\%3e2.0.CO;2

Blažeković Smojić S, Smajlović J, Koch G, Bulić J, Trutin M (2009) Source potential and palynofacies of Late Jurassic "Lemeš facies", Croatia. Org Geochem 40:833-845. https://doi.org/10. 1016/j.orggeochem.2009.05.005

Bray EE, Evans ED (1961) Distribution of $n$-parafins as a clue to recognition of source beds. Geochim Cosmochim Acta 22:2-15
Buchardt B, Christiansen FG, Nohr-Hansen H, Larsen NH, Ostfeldt P, Christiansen FG (1989) Composition of organic matter in source rocks. In: Christiansen (ed) Petroleum geology of North Greenland. Grønlands Geologiske Undersøgelse Bulletin, Copenhagen, pp 32-39

Bucković D, Markić A (2016) Correlation of carbonate strata in Gorski Kotar Area (Karst Dinarides, Croatia), An example of adriatic carbonate platform environmental diveristy during the Late Jurassic. Int J Earth Environ Sci 1:1-9. https://doi.org/10.15344/ 2456-351X/2016/113

Bucković D, Tešović BC, Gušić I (2004) Late Jurassic paleoenvironmental evolution of the Western Dinarides (Croatia). Geol Carpath 55:3-18

Bulić J, Trutin M (1996) Stratigraphic-sedimentological and geochemical research of Late Jurassic (Lemeš beds) in Plitvice-SvilajaWestern Bosnia area. INA Internal Report 1-53

Cemen I, Wright LA, Drake RE, Johnson FC (1985) Cenozoic sedimentation and sequence of deformational events at the southeastern end of the Furnace Creek strike-slip fault zone, Death Valley region, California. SEPM Spec Publ 37:128-141

Cota L, Baric G (1998) Petroleum potential of the Adriatic offshore, Croatia. Org Geochem 29:559-570. https://doi.org/10.1016/ S0146-6380(98)00130-2

Dahl B, Bojesen-Koefoed J, Holm A, Justwan H, Rasmussen E, Thomsen E (2004) A new approach to interpreting Rock-Eval S2 and TOC data for kerogen quality assessment. Org Geochem 35:1461-1477. https://doi.org/10.1016/j.orggeochem.2004.07. 003

Demaison G, Huizinga BJ (1994) Genetic classification of petroleum systems using three factors: charge, migration, and entrapment: Chapter 4: Part I. Introduction. In: Magoon LB, Dow WG (eds) The petroleum system-from source to trap. AAPG, pp 73-89

Didyk BM, Simoneit BRT, Brassell SC, Eglinton G (1978) Organic geochemical indicators of palaeoenvironmental conditions of sedimentation. Nature 272:216-222. https://doi.org/10.1038/ $272216 \mathrm{a} 0$

Dragičević I, Velic I (1994) Stratigraphical position and significance of reef facies at the Northern margin of the Dinaric carbonate platform during the Late Jurassic and Cretaceous in Croatia and Bosnia. Géologie Méditerranéenne 21:59-63. https://doi.org/10. 3406/geolm.1994.1526

Eglinton G, Hamilton RJ (1967) Leaf epicuticular waxes. Science 156:1322-1335. https://doi.org/10.1126/science.156.3780.1322

Einsele G (1992) Sedimentary basins — evolution, facies, and sediment budget. Springer, Berlin

Espitalié J, Marquis F, Barsony I (1984) Geochemical logging. In: Voorhees KJ (ed) Analytical pyrolysis. Elsevier, Butterworths, pp 276-304

Ficken KJ, Li B, Swain DL, Eglinton G (2000) An $n$-alkane proxy for the sedimentary input of submerged/floating freshwater aquatic macrophytes. Org Geochem 31:745-749

Fiket Ž, Alajbeg A, Palinkaš SS, Tari-Kovačić V, Palinkaš L, Spangenberg J (2008) Organic geochemistry of Jurassic-Cretaceous source rocks and oil seeps from the profile across the AdriaticDinaric carbonate platform. Geol Carpath 59:225-236

Flügel E (2004) Microfacies of carbonate rocks—analysis, interpretation and application, 1 st edn. Springer, Berlin

Frisch W (1979) Tectonic progradation and plate tectonic evolution of the Alps. Tectonophysics 60:121-139. https://doi.org/10.1016/ 0040-951(79)90155-0

Furlani M (1910) Die Lemeš-Schichten. Ein Beitrag zur Kenntnis der Juraformation in Mitteldalmatien. Jahrbuch Der K K Geologischen Reichsanstalt 60:67-98

Gawlick H-J, Missoni S (2019) Middle-Late Jurassic sedimentary mélange formation related to ophiolite obduction in the 
Alpine-Carpathian-Dinaridic Mountain Range. Gondwana Res 74:144-172. https://doi.org/10.1016/j.gr.2019.03.003

Gawlick H-J, Sudar M, Missoni S, Aubrecht R, Schlagintweit F, Jovanović D, Mikuš T (2020) Formation of a Late Jurassic carbonate platform on top of the obducted Dinaridic ophiolites deduced from the analysis of carbonate pebbles and ophiolitic detritus in southwestern Serbia. Int J Earth Sci 109:2023-2048. https://doi.org/10.1007/s00531-020-01886-w

Grantham PJ (1986) The occurrence of unusual $\mathrm{C}_{27}$ and $\mathrm{C}_{29}$ sterane predominances in two types of Oman crude oil. Org Geochem 9:1-10. https://doi.org/10.1016/0146-6380(86)90077-X

Hallam A (1984) Continental humid and arid zones during the Jurassic and cretaceous. Palaeogeogr Palaeoclimatol Palaeoecol 47:195223. https://doi.org/10.1016/0031-0182(84)90094-4

Haq BU (2018) Jurassic sea-level variations: a reappraisal. GSA Today 1:4-10. https://doi.org/10.1130/GSATG359A.1

Haq B, Hardenbol J, Vail P (1988) Mesozoic and Cenozoic chronostratigraphy and eustatic cycles. Sea-level changes: an integrated approach. SEPM, pp 71-108

Herak M (1986) A new concept of geotectonics of the Dinarides. Acta Geologica 16:1-42

Hollander DJ, Smith MA (2001) Microbially mediated carbon cycling as a control on the $\delta 13 \mathrm{C}$ of sedimentary carbon in eutrophic Lake Mendota (USA): new models for interpreting isotopic excursions in the sedimentary record. Geochim Cosmochim Acta 65:4321-4337. https://doi.org/10.1016/S0016-7037(00)00506-8

Hrvatski geološki institut (2009a) Geološka karta Republike Hrvatske, M 1:300.000

Hrvatski geološki institut (2009b) Tumač geološke karte Republike Hrvatske 1:300.000

Hughes WB, Holba AG, Dzou LIP (1995) The ratios of dibenzothiophene to phenanthrene and pristane to phytane as indicators of depositional environment and lithology of petroleum source rocks. Geochim Cosmochim Acta 59:3581-3598. https://doi. org/10.1016/0016-7037(95)00225-O

Jacob H, Jenko K, Spaic V (1983) Dispersed solid to semisolid natural oils and bitumens of the Yugoslav Adriatic coastal area (outer Dinarides). Nafta 34:693-700

Jenkyns HC (2010) Geochemistry of oceanic anoxic events: review. Geochem Geophys Geosyst 11:1-30. https://doi.org/10.1029/ 2009GC002788

Jenkyns HC, Jones CE, Gröcke DR, Hesselbo SP, Parkinson DN (2002) Chemostratigraphy of the Jurassic System: applications, limitations and implications for palaeoceanography. J Geol Soc 159:351-378. https://doi.org/10.1144/0016-764901-130

Jerinic V (1994) Upper Cretaceous organic-rich laminated limestones of the Adriatic Carbonate Platform, Island of Hvar, Croatia. AAPG Bull 78:1313-1321. https://doi.org/10.1306/A25FEADB171B-11D7-8645000102C1865D

Kerner FV (1907) Lias und Jura auf der Südseite der Svilaja planina. Verhandlungen Der K K Geologischen Reichsanstalt 11:268-281

Küspert W (1982) Environmental changes during oil shale deposition as deduced from stable isotope ratios. In: Einsele G, Seilacher A (eds) Cyclic and event stratification. Springer, Berlin, pp 482-501

Lafargue E, Marquis F, Daniel P (1998) Rock-Eval 6 applications in hydrocarbon exploration, production, and soil contamination studies. Oil Gas Sci Technol 53:421-437. https://doi.org/10. 2516/ogst:1998036

Langford FF, Blanc-Valleron M-M (1990) Interpreting Rock-Eval pyrolysis data using graphs of pyrolyzable hydrocarbons versus total organic carbon. AAPG Bull 74:799-804

Lawrence R, Tari-Kovacic V, Gjukic B (1995) Geological evolution model of the Dinarides. Nafta 42:102-113
Lefeld J, Radwanski A (1960) Les Crinoides planctoniques Saccocoma Agassiz dans le Malm et le Necomien Haut Tatrique des Tatras polonaises. Acta Geologica Poland 10:593-614

Lewan MD, Ruble TE (2002) Comparison of petroleum generation kinetics by isothermal hydrous and nonisothermal open-system pyrolysis. Org Geochem 33:1457-1475. https://doi.org/10.1016/ S0146-6380(02)00182-1

Liu Z, Chen D, Zhang J, Lü X, Wang Z, Liao W, Shi X, Tang J, Xie G (2019) Pyrite morphology as an indicator of Paleoredox conditions and shale gas content of the Longmaxi and Wufeng Shales in the Middle Yangtze Area, South China. Minerals 9:1-18. https://doi.org/10.3390/min9070428

Luo G, Algeo TJ, Huang J, Zhou W, Wang Y, Yang H, Richoz S, Xie $S$ (2014) Vertical $\delta^{13} C_{\text {org }}$ gradients record changes in planktonic microbial community composition during the end-Permian mass extinction. Palaeogeogr Palaeoclimatol Palaeoecol 396:119-131. https://doi.org/10.1016/j.palaeo.2014.01.006

Mackenzie AS, Patience RL, Maxwell JR, Vandenbroucke M, Durand B (1980) Molecular parameters of maturation in the Toarcian shales, Paris Basin, France-I. Changes in the configurations of acyclic isoprenoid alkanes, steranes and triterpanes. Geochim Cosmochim Acta 44:1709-1721. https://doi.org/10.1016/00167037(80)90222-7

Marshall JD (1992) Climatic and oceanographic isotopic signals from the carbonate rock record and their preservation. Geol Mag 129:143-160. https://doi.org/10.1017/S0016756800008244

Mattavelli L, Pieri M, Groppi G (1993) Petroleum exploration in Italy: a review. Mar Pet Geol 10:410-425. https://doi.org/10.1016/ 0264-8172(93)90044-S

Missoni S, Gawlick H-J (2011) Evidence for Jurassic subduction from the Northern Calcareous Alps (Berchtesgaden; Austroalpine, Germany). Int J Earth Sci 100:1605-1631. https://doi.org/10. 1007/s00531-010-0552-Z

Moldowan JM, Fago FJ (1986) Structure and significance of a novel rearranged monoaromatic steroid hydrocarbon in petroleum. Geochim Cosmochim Acta 50:343-351. https://doi.org/10.1016/ 0016-7037(86)90188-2

Moldowan JM, Seifert WK, Gallegos EJ (1985) Relationship between petroleum composition and depositional environment of petroleum source rocks. Bulletin 69:1255-1268. https://doi.org/10. 1306/AD462BC8-16F7-11D7-8645000102C1865D

Moldowan JM, Lee CY, Sundararaman P, Salvatori T, Alajbeg A, Gjukic B, Demaison GJ (1992) Source correlation and maturity assessment of select oils and rocks from the central Adriatic basin (Italy and Yugoslavia), vol 34. American Chemical Society, Division of Petroleum Chemistry, $\mathrm{p} 1$ (Preprints)

Moliner L, Olóriz F (2009) Updated biostratigraphy of Jurassic (lower Kimmeridgian) deposits containing the ammonite Ataxioceras from the eastern Iberian Range, northeastern Spain. GFF 131:195-203. https://doi.org/10.1080/11035890902952886

Moliner L, Olóriz F (2010) New Lower Kimmeridgian Ataxioceratin Ammonite from the Eastern Iberian Chain, Spain: systematic, biogeographic, and biostratigraphic relevance. Acta Palaeontol Pol 55:99-110. https://doi.org/10.4202/app.2008.0064

O’Dogherty L, Aguado R, Baumgartner PO, Bill M, Goričan Š, Sandoval J, Sequeiros L (2018) Carbon-isotope stratigraphy and pelagic biofacies of the Middle-Upper Jurassic transition in the Tethys-Central Atlantic connection. Palaeogeogr Palaeoclimatol Palaeoecol 507:129-144. https://doi.org/10.1016/j.palaeo.2018. 07.006

Peters KE, Cassa MR (1994) Applied source rock geochemistry: Chapter 5: Part II. Essential elements. In: Magoon LB, Dow WG (eds) The petroleum system-from source to trap. AAPG, pp 93-120

Peters KE, Walters CC, Moldowan JM (2005) The biomarker guide, 2nd edn. Cambridge University Press, Cambridge 
Peters KE, Hackley PC, Thomas JJ, Pomerantz AE (2018) Suppression of vitrinite reflectance by bitumen generated from liptinite during hydrous pyrolysis of artificial source rock. Org Geochem 125:220-228. https://doi.org/10.1016/j.orggeochem.2018.09.010

Picotti V, Cobianchi M (2017) Jurassic stratigraphy of the Belluno Basin and Friuli Platform: a perspective on far-field compression in the Adria passive margin. Swiss J Geosci 110:833-850. https://doi.org/10.1007/s00015-017-0280-5

Porkoláb K, Kövér S, Benkó Z, Héja GH, Fialowski M, Soós B, Spajić NG, Đerić N, Fodor L (2019) Structural and geochronological constraints from the Drina-Ivanjica thrust sheet (Western Serbia): implications for the Cretaceous-Paleogene tectonics of the Internal Dinarides. Swiss J Geosci 112:217-234. https://doi.org/ 10.1007/s00015-018-0327-2

Radke M (1988) Application of aromatic compounds as maturity indicators in source rocks and crude oils. Mar Pet Geol 5:224-236

Radke M, Welte DH (1981) The methylphenanthrene index (MPI): a maturity parameter based on aromatic hydrocarbons. Advances in organic geochemistry. Wiley, Chichester, pp 504-512

Radke M, Willsch H, Welte DH (1980) Preparative hydrocarbon group type determination by automated medium pressure liquid chromatography. Anal Chem 52:406-411. https://doi.org/10.1021/ ac50053a009

Radovčić J, Tišljar J, Jelaska V (1983) Upper Cretaceous Fish-bearing Platy Limestones in Central Dalmatia. In: Babić L, Jelaska V (eds) Contribution to sedimentology of same carbonate and clastic units of the Costal Dinarides, Excursion Guidebook. 4th IAS regional meeting, International association of sedimentologists, Split, pp 79-85.

Ratschbacher L, Dingeldey C, Miller C, Hacker BR, McWilliams MO (2004) Formation, subduction, and exhumation of Penninic oceanic crust in the Eastern Alps: time constraints from 40Ar/39Ar geochronology. Tectonophysics 394:155-170. https://doi.org/10. 1016/j.tecto.2004.08.003

Riolo J, Hussler G, Albrecht P, Connan J (1986) Distribution of aromatic steroids in geological samples: their evaluation as geochemical parameters. Org Geochem 10:981-990. https://doi.org/ 10.1016/S0146-6380(86)80036-5

Saltzman MR, Thomas E (2012) Carbon isotope stratigraphy. In: Gradstein FM, Ogg JG, Schmitz MD, Ogg GM (eds) The geologic time scale. Elsevier, pp 207-232

Schlager W (2005) Carbonate sedimentology and sequence stratigraphy. SEPM, Tulsa

Schlagintweit F, Gawlick H-J, Missoni S, Hoxha L, Lein R, Frisch W (2008) The eroded Late Jurassic Kurbnesh carbonate platform in the Mirdita Ophiolite Zone of Albania and its bearing on the Jurassic orogeny of the Neotethys realm. Swiss J Geosci 101:125-138. https://doi.org/10.1007/s00015-008-1254-4

Schmid SM, Bernoulli D, Fügenschuh B, Maţenco L, Schefer S, Schuster R, Tischler M, Ustaszewski K (2008) The Alpine-Carpathian-Dinaridic orogenic system: correlation and evolution of tectonic units. Swiss J Geosci 101:139-183. https://doi.org/10. 1007/s00015-008-1247-3

Schmid SM, Fügenschuh B, Kounov A, Maţenco L, Nievergelt P, Oberhänsli R, Pleuger J, Schefer S, Schuster R, Tomljenović B, Ustaszewski K, van Hinsbergen DJJ (2020) Tectonic units of the Alpine collision zone between Eastern Alps and western Turkey. Gondwana Res 78:308-374. https://doi.org/10.1016/j. gr.2019.07.005

Schultz LG (1964) Quantitative interpretation of mineralogical composition from X-ray and chemical data for the Pierre Shale. Geological Survey Professional Paper 391-C. https://doi.org/10.3133/ pp391C

Sebecic B, Ercegovac M (1983) A contribution to the knowledge of kerogen maturity in some bituminous carbonate deposits of the Outer Dinarides. Nafta 34:183-188
Šegvić B, Toševski A, Števanić D, Biševac V, Lugović B (2006) Altered tephra layers in the Upper Jurassic Lemeš deposits near Maovice (Dalmatia, Croatia): clay mineralogy and basic soil mechanic properties. In: Vlahović I, Tibljaš D, Durn G, Biševac V (eds) 3rd Mid-European Clay Conference-MECC 06: Abstracts Book. Faculty of Science, Opatija, p 104

Seifert WK, Moldowan JM (1980) The effect of thermal stress on source-rock quality as measured by hopane stereochemistry. Phys Chem Earth 12:229-237. https://doi.org/10.1016/0079-1946(79) 90107-1

Seifert W, Moldowan J (1986) Use of biological markers in petroleum exploration. In: Johns R (ed) Methods in geochemistry and geophysics. Elsevir, Amsterdam, pp 261-290

Sinninghe Damsté JS, Kenig F, Koopmans MP, Köster J, Schouten S, Hayes JM, de Leeuw JW (1995) Evidence for gammacerane as an indicator of water-column stratification. Geochim Cosmochim Acta 59:1895-1900

Steel R, Gloppen TG (1980) Late Caledonian (Devonian) basin formation, western Norway: signs of strike-slip tectonics during infilling. SEPM Spec Publ 4:79-103

Taylor G, Teichmüller M, Davis A, Diessel CFK, Littke R, Robert P (1998) Organic petrology. Gebrüder Borntraeger, Berlin

Ten Haven HL, Leeuw JWD, Peakman TM, Maxwell JR (1986) Anomalies in steroid and hopanoid maturity indices. Geochim Cosmochim Acta 50:853-855. https://doi.org/10.1016/0016-7037(86) 90361-3

Thiel V, Peckmann J, Seifert R, Wehrung P, Reitner J, Michaelis W (1999) Highly isotopically depleted isoprenoids: molecular markers for ancient methane venting. Geochim Cosmochim Acta 63:3959-3966. https://doi.org/10.1016/S0016-7037(99)00177-5

Tišljar J, Velić I (1993) Upper Jurassic (Malm) Shallow-Water carbonates in the Western Gorski Kotar Area: facies and depositional environments (Western Croatia). Geologia Croatica 46:263-279

Tišljar J, Velic I, Vlahović I (1994) Facies diversity of the Malmian platform carbonates in Western Croatia as a consequence of synsedimentary tectonics. Géologie Méditerranéenne 21:173-176. https://doi.org/10.3406/geolm.1994.1557

Tissot BP, Pelet R, Ungerer PH (1987) Thermal history of sedimentary basins, maturation indices, and kinetics of oil and gas generation. Bulletin 71:1445-1466. https://doi.org/10.1306/703C80E7-170711D7-8645000102C1865D

Velić I (2007) Stratigraphy and palaeobiogeography of Mesozoic Benthic Foraminifera of the Karst Dinarides (SE Europe). Geologia Croatica 60:1-113

Velić I, Vlahović I, Tišljar J (1994) Late Jurassic lateral and vertical facies distribution: from peritidal and inner carbonate ramps to perireefal and peritidal deposits in SE Gorski Kotar (Croatia). Géologie Méditerranéenne 21:177-180. https://doi.org/10.3406/ geolm.1994.1558

Velić I, Tišljar J, Vlahović I, Velić J, Koch G, Matičec D (2002a) Palaeogeographic Variability and Depositional Environments of the Upper Jurassic Carbonate Rocks of Velika Kapela Mt. (Gorski Kotar Area, Adriatic Carbonate Platform, Croatia). Geologia Croatica 55:121-138

Velić I, Vlahović I, Matičec D (2002b) Depositional sequences and palaeogeography of the Adriatic carbonate platform. Memorie Della Società Geologica Italiana 57:141-151

Veseli V, Troskot-Crbić T, Velić I, Vlahović I, Tomljenović B, Velić J (2012) Sedimentary dynamics in the central part of the Adriatic Carbonate Platform from the Late Oxfoordian to the Early Tithonian (Postak Mt., Croatia). In: 29th IAS Meeting, Schladming, Abstract book, p 475

Vlahović I, Velić I, Tišljar J, Matičec D, Dragičević I (2001) Malmian palaeogeography of the Adriatic carbonate platform as a consequence of the synsedimentary tectonics. In: Dragičević I, Velić I 
(eds) The first Scientific Meeting: Carbonate Platform or Carbonate Platforms of Dinarides. Abstract. pp 51-54

Vlahović I, Tišljar J, Velić I, Matičec D (2005) Evolution of the Adriatic Carbonate Platform: palaeogeography, main events and depositional dynamics. Palaeogeogr Palaeoclimatol Palaeoecol 220:333-360. https://doi.org/10.1016/j.palaeo.2005.01.011

Volkman J (1988) Biological marker compounds as indicators of the depositional environments of petroleum source rocks. Geol Soc Lond Spec Publ 40:103-122. https://doi.org/10.1144/GSL.SP. 1988.040.01.10

Weissert H, Erba E (2004) Volcanism, $\mathrm{CO}_{2}$ and palaeoclimate: a Late Jurassic-Early Cretaceous carbon and oxygen isotope record. J Geol Soc 161:695-702. https://doi.org/10.1144/ 0016-764903-087

Wierzbowski A (2017) The Lower Kimmeridgian of the Wieluń Upland and adjoining regions in central Poland: lithostratigraphy, ammonite stratigraphy (upper Planula/Platynota to Divisum zones), palaeogeography and climate-controlled cycles. Volumina Jurassica 15:41-120. https://doi.org/10.5604/01.3001.0010.5659

Wilkin RT, Barnes HL, Brantley SL (1996) The size distribution of framboidal pyrite in modern sediments: an indicator of redox conditions. Geochim Cosmochim Acta 60:3897-3912. https:// doi.org/10.1016/0016-7037(96)00209-8 